\title{
Functional Characteristics of Reversibly Immortalized Hepatic Progenitor Cells Derived from Mouse Embryonic Liver
}

\author{
Yang $\mathrm{Bi}^{\mathrm{a}, \mathrm{b}}$ Yun He $\mathrm{H}^{\mathrm{a}, \mathrm{b}, \mathrm{c}}$ Jiayi Huang ${ }^{\mathrm{a}, \mathrm{c}}$ Yuxi Su${ }^{\mathrm{a}, \mathrm{b}, \mathrm{c}}$ Gao-Hui Zhu ${ }^{\mathrm{a}, \mathrm{b}, \mathrm{c}}$ Yi Wang ${ }^{\mathrm{a}, \mathrm{b}, \mathrm{c}}$ \\ Min Qiao ${ }^{c, d}$ Bing-Qiang Zhang ${ }^{c, d}$ Hongyu Zhang ${ }^{c, d}$ Zhongliang Wang ${ }^{a, b, c}$ \\ Wei Liu ${ }^{a, b, c}$ Jing Cuic,e Quan Kanga,b,c Zhonglin Zhang ${ }^{c, f}$ Youlin Deng ${ }^{c, d}$ \\ Ruifang Lic,f Qian Zhang ${ }^{a, b, c}$ Ke Yang ${ }^{a, b, c}$ Hue H. Luu ${ }^{c}$ Rex C. Haydon ${ }^{c}$ \\ Tong-Chuan He $\mathrm{H}^{\mathrm{a}, \mathrm{b}, \mathrm{c}}$ Ni Tange
}

\begin{abstract}
aStem Cell Biology and Therapy Laboratory, Ministry of Education Key Laboratory of Child Development and Disorders, the Children's Hospital of Chongqing Medical University, Chongqing, China; ; Chongqing Stem Cell Therapy Engineering and Technology Center, Chongqing, China; 'Molecular Oncology Laboratory, Department of Orthopaedic Surgery, The University of Chicago Medical Center, Chicago, Illinois, USA; dDepartments of Gastroenterology, Surgery and Gynecology, the First Affiliated Hospital of Chongqing Medical University, Chongqing, China; eMinistry of Education Key Laboratory of the Molecular Biology of Infectious Diseases and the Second Affiliated Hospital

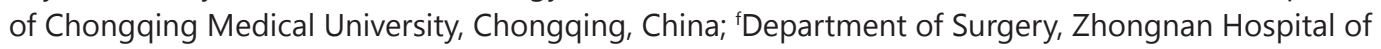
Wuhan University, Wuhan, China
\end{abstract}

\section{Key Words}

Hepatic progenitor cells • Liver stem cells • Reversible immortalization • SV40 large T antigen - Hepatic differentiation $\cdot$ Hepatocyte transplantation

\begin{abstract}
Background/Aims: Liver is a vital organ and retains its regeneration capability throughout adulthood, which requires contributions from different cell populations, including liver precursors and intrahepatic stem cells. To overcome the mortality of hepatic progenitors (iHPs) in vitro, we aim to establish reversibly immortalized hepatic progenitor cells from mouse embryonic liver. Methods and Results: Using retroviral system to stably express SV40 $\mathrm{T}$ antigen flanked with Cre/LoxP sites, we establish a repertoire of iHP clones with varied differentiation potential. The iHP cells maintain long-term proliferative activity and express varied levels of progenitor markers (Pou5f1/Oct4 and Dlk) and hepatocyte markers (AFP, Alb and $\mathrm{ApoB}$ ). Five representative iHP clones express hepatic/pancreatic transcription factors HNF3 $\alpha / F o x a 1, H N F 3 \beta / F o x a 2$, and HNF4 $\alpha / M O D Y 1$. Dexamethasone is shown to promote the expression of hepatocyte markers AFP and TAT, along with ICG-uptake and glycogen storage functions in the iHP clones. Cre-mediated removal of SV40 T antigen reverses the proliferative activity of iHP cells. When iHP cells are subcutaneously implanted in athymic nude mice,

T.-C. He, MD, PhD

and Ni Tang, MD, PhD

Molecular Oncology Laboratory, The University of Chicago Medical Center

5841 South Maryland Avenue, MC 3079, Chicago, IL 60637 (USA)

and The Second Affiliated Hospital, Chongqing Medical University, Chongqing (China)

E-Mail tche@uchicago.edu, E-Mail nitang809@hotmail.com
\end{abstract}


no tumor formation is observed for up to 8 weeks. Conclusions: We demonstrate that the established iHP cells are stable, reversible, and non-tumorigenic hepatic progenitor-like cells, which should be valuable for studying liver organogenesis, metabolic regulations, and hepatic lineage-specific differentiation.

Copyright (C) 2014 S. Karger AG, Basel

\section{Introduction}

As a major metabolic organ of the body, liver regulates diverse functions during growth, development and adulthood [1]. Liver serves as the first site of embryonic hematopoiesis, but turns into a vital detoxifying system in the postnatal period. Liver also serves as a major storage of glycogen and vitamin $\mathrm{A}$, and remains as one of a few organs in the adult capable of regeneration [2]. While normal mature hepatocytes exhibit quiescent phenotype, stay in the G0 phase of the cell cycle, and show minimal turnover, upon hepatocyte loss, the mature hepatocytes undergo cell division. In response to acute injuries, hepatocytes and cholangiocytes can undergo cell proliferation to compensate the lost cells, a process called liver regeneration. However, severe chronic damage caused by liver diseases can significantly diminish the proliferative ability of these cells for liver regeneration and liver organ transplantation may be required [2-6]. While liver organ transplantation has been a life-saving measure for many end-stage liver disease patients, the scarcity of liver donors poses significant challenges to this practice $[2,6,7]$.

Liver regeneration is a rapid and well-coordinated process thatrequires the contributions from different cell populations, including hepatocytes, liver precursor cells, and intrahepatic stem cells. While mature hepatocytes are capable of proliferating and give rise to new hepatocytes and cholangiocytes, liver stem cells (or so-called oval cells) are the important bipotential precursors in compensating the cellular loss and maintaining liver homeostasis [1]. The progenitor-like properties of differentiating hepatocytes provide opportunities for the hepatocyte transplantation which is an appealing alternative to auxiliary orthotropic liver transplantation $[2,6,7]$. In fact, hepatocyte transplantation has been attempted to treat genetic diseases, such as familial hypercholesterolemia, Crigler-Najjar syndrome type I, glycogen storage disease type $1 \mathrm{a}$, urea cycle defects and congenital deficiency of coagulation factor VII $[8,9]$. Thus, there is an urgent need to facilitate the potential use of liver progenitor cells in clinical settings [10].

Liver primarily comprises of two epithelial cell lineages, namely, hepatocytes and cholangiocytes which are originated from hepatoblasts during fetal developing stages [11]. While the true origin and nature of liver stem cells remains an area of intensive investigation, it is generally accepted that hepatoblasts are the major source of the liver progenitor cell in development $[1,2]$. The onset of mouse liver development starts at embryonic day (E) 8.5 from the foregut endoderm, which is derived from medial and lateral domains of developing ventral foregut [12]. While numerous studies reported that hepatocytes can be derived from embryonic stem cells, mesenchymal stem cells, and iPS cells [13-28], liver progenitor cells have been isolated from both fetal and adult liver tissues, which have the capacity for unlimited proliferation and multilineage differentiation [1,21, 29-36]. Although it has been reported that relatively long-term culturing of liver progenitor cells can be achieved under special culture conditions [31, 37-39], the primary progenitor cells usually have limited life span in vitro $[40,41]$. Thus, it is desirable to establish stable hepatic progenitor cells, which are non-tumorigenic and maintain the stem cell properties, as these cells may provide a unique system to study stem cell regulation and to optimize conditions for directing endogenous regenerative potential towards a lineage-specific differentiation.

To overcome the mortality issue of hepatic progenitor cells in vitro, here we establish the reversibly immortalized hepatic progenitor (iHP) cells from mouse fetal liver tissues by stably expressing SV40 T antigen, which is flanked with Cre/LoxP sites. Limiting-dilution cloning of the iHP cells creates a repertoire of hepatic progenitor clones with varied differentiation potential. The iHP cells maintain long-term proliferative activity and express progenitor 
markers and hepatocyte-related markers. Upon dexamethasone (Dex) stimulation, the iHP cells are able to express mature hepatocyte markers and perform ICG uptake and glycogen storage functions. Cre recombinase-mediated removal of SV40 T antigen reverses the proliferative activity of the iHP cells. When the iHP cells are subcutaneously implanted in the athymic nude mice, no tumor formation is observed for up to 8 weeks. Therefore, our results demonstrate that the established iHP cells are stable, reversible, and nontumorigenic progenitor-like cells. The iHP cells should be a valuable resource for studying stem cell biology, liver organogenesis, and metabolic regulations, hepatic tumorigenesis, and identifying factors involved in directed lineage-specific differentiation for potential hepatocyte transplantation as a treatment of liver diseases.

\section{Materials and Methods}

\section{Cell culture medium and chemicals}

HEK-293 and mouse hepatoma Hepa1-6 cell lines were obtained from ATCC (Manassas, VA) and maintained in complete Dulbecco's modified Eagle's medium (DMEM) as described [42-45]. For hepatic differentiation induction, cells were treated with complete medium containing $0.1 \mu \mathrm{mol} / \mathrm{L}$ dexamethasone (Dex) as described [46, 47]. Unless indicated otherwise, all chemicals were purchased from Sigma-Aldrich (St. Louis, MO, USA).

\section{Isolation of hepatic progenitor cells from mouse embryonic liver tissues}

The animal welfare, use, and care were carried out according to the approved protocol by the Institutional Animal Care and Use Committee. Post coitus day 11.5 to 14.5 mouse embryos from the timed pregnant CD1 female mice were obtained from The University of Chicago Transgenic Core Facility for isolating primary fetal hepatic progenitor cells as described [46-48]. Briefly, the fetal liver tissues were dissected out, rinsed with cold sterile PBS, and minced into pieces smaller than $1.0 \mathrm{~mm}^{3}$, followed by incubation in $0.25 \%$ trypsin $/ 1 \mathrm{mM}$ EDTA with gentle agitations at $37^{\circ} \mathrm{C}$ for $10 \sim 15 \mathrm{~min}$. Then, $10 \mathrm{ml}$ of complete DMEM were added to inactivate trypsin, and the digested cell/tissue mixture was filtered through $100 \mu \mathrm{m}$ strainers to remove cell/tissue debris. Recovered cells were seeded on $100 \mathrm{~mm}$ cell culture dishes pre-coated with type I collagen and incubated at $37^{\circ} \mathrm{C}$ and $5 \% \mathrm{CO}_{2}$. After $24 \mathrm{~h}$, medium was changed and non-adherent cells were removed. When reaching approximately $90 \%$ confluence, the isolated primary cells were passaged for making stable cell lines.

\section{Establishment of stable embryonic hepatic progenitor cell lines}

The retroviral vector SSR\#69 expressing SV40 large T antigen flanked with LoxP sites and pCLAmpho packaging vector were co-transfected into HEK-293 cells to produce packaged retrovirus as described [4954]. Subconfluent primary fetal liver cells isolated above were infected with retrovirus and selected with hygromycin B $(0.3 \mathrm{mg} / \mathrm{mL}$, Invitrogen) for $7 \sim 10$ days. The stable cells were collected by trypsinization, serially diluted, and plated in 96-well cell culture plates using limiting dilution cloning method. Clones derived from single cells were selected and scaled up for further characterization while clone stocks were kept in liquid nitrogen tanks. Clones were designated as immortalized hepatic progenitors (iHP) and distinguished by their embryonic stages. For example, iHP13 clones indicate those immortalized clones that were derived from the hepatic progenitors obtained from E13.5 liver tissues.

As a control line for mature hepatocytes, the primary hepatocytes were isolated from 14-day-old CD1 mouse liver tissues and immortalized in a similar fashion as described above. The resultant stable cells were designated as LC14d. Mouse hepatoma Hepa1-6 line was also used as a control.

Recombinant adenoviruses expressing Cre recombinase (Ad-Cre), firefly luciferase (Ad-FLuc), and green fluorescent protein (Ad-GFP)

Recombinant adenoviruses were generated using the AdEasy technology $[55,56]$. The coding regions of Cre recombinase and firefly luciferase (FLuc) were PCR amplified and subcloned into an adenoviral shuttle vector and subsequently used to generate recombinant adenoviruses in our recently engineered packaging line 293pTP [57], resulting in adenoviruses Ad-Cre and Ad-FLuc, which also express GFP as a marker for monitoring infection efficiency. Analogous adenovirus only expressing GFP (Ad-GFP) was used 
Table 1. Primers used for qPCR and cloning

\begin{tabular}{|c|c|c|}
\hline Name & Oligo Sequence & Use \\
\hline \multirow{2}{*}{ Mouse GAPDH } & GGCTGCCCAGAACATCAT & \multirow{24}{*}{ qPCR } \\
\hline & CGGACACATTGGGGGTAG & \\
\hline \multirow{2}{*}{ Mouse CD34 } & GGTTGGCCCAGGGTATCT & \\
\hline & ACCAGCATCAGCCTCAGC & \\
\hline \multirow{2}{*}{ Mouse Pou5f1/Oct4 } & CTGTGGACCTCAGGTTGGA & \\
\hline & CAGGGCTCAGAGGAGGTTC & \\
\hline \multirow{2}{*}{ Mouse AFP } & CACTGCTGCAACTCTTCGTA & \\
\hline & CTTTGGACCCTCTTCTGTGA & \\
\hline \multirow{2}{*}{ Mouse Dlk } & ACAATGGAACTTGCGTGGA & \\
\hline & GGCAGGGAGAACCATTGAT & \\
\hline \multirow{2}{*}{ Mouse Alb } & TGTCTTCCTGGGCACGTT & \\
\hline & GCTTCAGCGCAGCACTTT & \\
\hline \multirow{2}{*}{ Mouse CK18 } & CTGGGCTCTGTGCGAACT & \\
\hline & ACAGAGCCACCCCAGACA & \\
\hline \multirow{2}{*}{ Mouse TAT } & ACCTTCAATCCCATCCGA & \\
\hline & TCCCGACTGGATAGGTAG & \\
\hline \multirow{2}{*}{ Mouse ApoB } & CATGTGATCCCCACAGCA & \\
\hline & TCCCAGGACCATGGAAAA & \\
\hline \multirow{2}{*}{ Mouse HNF3 $\alpha /$ Foxa1 } & TGTTCGAGAACGGCTGCT & \\
\hline & GAGGGGTCCTTGCGACTT & \\
\hline \multirow{2}{*}{ Mouse HNF3 $\beta /$ Foxa } & GCCCCGGGACTTAACTGT & \\
\hline & GGCTCCGCGTAGTAGCTG & \\
\hline \multirow{2}{*}{ Mouse HNF4 $\alpha$ /MODY1) } & GGCAGTCAAGGCTCAGGA & \\
\hline & CGCTAACTGCTGGGGATG & \\
\hline Cre recombinase & $\begin{array}{l}\text { CGGGGTACCATGGGCATGTCCAATTTACTGACCGTACAC } \\
\text { CCCAAGCTTCTAATCGCCATCTTCCAGCAGGCG }\end{array}$ & \multirow{5}{*}{ cloning } \\
\hline Firefly luciferease & CGG GGTACCATGGAAGACGCCAAAAACATAAAGAAAG & \\
\hline Frreny rucmerease & CGCGTCGACTTACACGGCGATCTTTCCGCCCTTC & \\
\hline \multirow{2}{*}{ GFP } & CCCAAGCTTGCCACCATGGTGAGCAAGGGCG & \\
\hline & CGCGGATCCTTACTTGTACAGCTCGTCCATGCCG & \\
\hline
\end{tabular}

as a control [44, 58-66]. For all adenovirus infections, polybrene $(8 \mu \mathrm{g} / \mathrm{ml})$ was added to the culture medium in order to enhance transgene transduction efficiency [67].

RNA isolation, quantitative and semi-quantitative RT-PCR ( $q$ PCR and sqPCR) analyses

Freshly prepared mouse liver tissues at the indicated development stages were dissected out, rinsed with PBS, minced, and then homogenized in the TRIzol reagent (Invitrogen). For the cultured cells, subconfluent cells were seeded in $60 \mathrm{~mm}$ dishes in a complete DMEM with different treatments. Total RNA was extracted using the TRIzol reagent according to the manufacturer's instructions. The cDNA synthesis was carried out using hexamer and Superscript II Reverse Transcriptase RT (Invitrogen). The cDNA products were diluted 10- to 100-fold and used as PCR templates. 18 20 mers of primers were designed with the Primer3.0 program to amplify the genes of interest (Table 1). PCR products were approximately 100 150 bps. SYBR Green-based qPCR analysis was carried out by using the thermocycler Opticon II DNA Engine (Bio-Rad, CA) with a standard pUC19 plasmid as described elsewhere [48, 54]. The qPCR reactions were done in triplicate. The sqPCR was also carried out as described [58, 63, 68, 69]. Briefly, sqPCR reactions were carried out by using a touchdown protocol: $94^{\circ} \mathrm{C} \times 20^{\prime \prime}, 68^{\circ} \mathrm{C} \times 30^{\prime \prime}, 70^{\circ} \mathrm{C} \times 20^{\prime \prime}$ for 12 cycles, with $1^{\circ} \mathrm{C}$ decrease per cycle, followed by $25-30$ cycles at $94^{\circ} \mathrm{C} \times 20^{\prime \prime}, 56^{\circ} \mathrm{C} \times 30^{\prime \prime}, 70^{\circ} \mathrm{C} \times 20^{\prime \prime}$. PCR products were resolved on $1.5 \%$ agarose gels. All samples were normalized by the expression level of GAPDH.

\section{Indocyanine Green (ICG) uptake and release assay}

The ICG uptake and release assay was carried out as described [46, 47, 70]. Subconfluent iHP cells were plated in 24-well culture plates and treated with Dex $(0.1 \mu \mathrm{M})$ or DMSO for 10 days. Cells were washed with PBS and incubated with ICG $\left(1 \mathrm{mg} / \mathrm{mL}\right.$ in complete DMEM) at $37^{\circ} \mathrm{C}$ for $1 \mathrm{~h}$, followed by PBS washes. ICG uptake was observed and recorded under a bright field microscope. For ICG release detection, the ICGcontaining medium was changed with regular complete medium, and the cells were incubated for additional $6 \mathrm{~h}$. Stained cells were again observed under a microscope. Each assay condition was done in triplicate.

Periodic Acid-Schiff (PAS) staining

PAS staining was carried out as described [46, 47, 70]. Briefly, subconfluent iHP cells were seeded in 24-well culture plates and treated with Dex $(0.1 \mu \mathrm{M})$ or DMSO for 10 days. Cells were fixed with $4 \%$ paraformaldehyde for $10 \mathrm{~min}$, followed by stained with $0.5 \%$ periodic acid solution for $5 \mathrm{~min}$. After being 
rinsed in distilled water for $3 \mathrm{~min}$, cells were incubated in the Schiff's reagent for $15 \mathrm{~min}$, and counterstained with hematoxylin solution, followed by thorough rinses with tap water. Cell staining was recorded using a microscope. Each assay condition was done in triplicate.

\section{SV40 T antigen Western blotting analysis}

Western blotting was carried out as described [71-73]. Briefly, the iHP lines and control Hepa1-6 cells were seeded in $60 \mathrm{~mm}$ cell culture dishes and infected with Ad-Cre or Ad-GFP. At $48 \mathrm{~h}$ post infection,

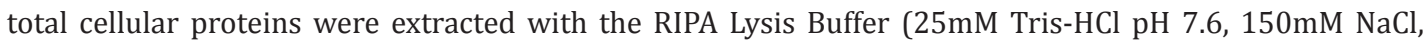
$1 \%$ NP-40, 1\% sodium deoxycholate, $0.1 \%$ SDS) and subjected to 8\% SDS-PAGE. The resolved proteins were electrically transferred to Immobilon-P membranes (Millipore). The membranes were blocked with SuperBlock Blocking Buffer (Pierce, Rockford, IL) at room temperature for $1 \mathrm{hr}$, followed by incubation with anti-SV40 T antigen or anti- $\beta$-actin antibody (Santa Cruz Biotechnology) at $4^{\circ} \mathrm{C}$ overnight, and probed with appropriate secondary antibodies conjugated with horseradish peroxidase (Santa Cruz Biotechnology) at room temperature for $1 \mathrm{~h}$. The presence of the proteins was visualized by using the SuperSignal West Pico Chemiluminescent Substrate kit (Pierce) with the Kodak 440CF Image Station.

Cell viability Trypan Blue staining assay

Cell viability was measured using the Trypan blue exclusion assay as described $[8,61,74]$. Briefly, subconflucent iHP lines and Hepa1-6 cells were seeded in 24-well culture plates and infected with AdCre or Ad-GFP. The infected cells were collected at the indicated time points and mixed with Trypan Blue buffer (final concentration at $0.1 \%$ Trypan blue). Viable cells of the stained cell mixtures were subjected to hemocytometer cell counting under a microscope. Each assay condition was done in triplicate.

\section{Albumin promoter-driven Gaussia luciferase (Alb-GLuc) reporter assay}

The homemade pSEB-Alb-GLuc reporter contains the mouse 2.5 -kb albumin promoter sequence that drives the expression of Gaussia luciferase [46-48]. Subconfluent iHP14-19 cells were seeded in 24-well culture plates, transfected with pSEB-Alb-GLuc plasmid using LipofectAmine reagent (Invitrogen), infected with Ad-Cre or Ad-GFP, and treated with Dex $(0.1 \mu \mathrm{M})$ or DMSO for 10 days. At the indicated time points, culture medium was collected for Gaussia luciferase assays using the Gaussia Luciferase Assay Kit (New England Biolabs). All assays were performed in triplicate.

\section{In vivo cell implantation and Xenogen bioluminescence imaging}

The use and care of animals was approved by the Institutional Animal Care and Use Committee. Subconfluent iHP lines and Hepa1-6 cells were co-infected with Ad-FLuc and Ad-Cre or Ad-GFP for 24h. The infected cells $\left(5 \times 10^{6}\right.$ cells/injection) were collected and injected subcutaneously into the flanks of athymic nude mice (male, 4-6 wk old, Harlem Research Laboratory; 5 animals/group). At 1 day, 1 week and 2 weeks after implantation, the animals were subjected to bioluminescence imaging using Xenogen IVIS 200 imaging system as described $[50,61,63,73,75,76]$. Mice were injected (i.p.) with D-Luciferin sodium salt (Gold BioTechnology) at $100 \mathrm{mg} / \mathrm{kg}$ in $0.1 \mathrm{ml}$ PBS. The pseudo images were obtained by superimposing the emitted light over the gray-scale photographs of the mice. Quantitative analysis was done with Xenogen's Living Image software.

\section{Statistical analysis}

All quantitative data were presented as mean \pm SD. The two-tailed student's $t$ test was used for statistical analysis. In all assays, the probability value $(p)$ of $<0.05$ was considered statistically significant. Error bars represent the SD of three independent experiments.

\section{Results}

Endogenous expression of hepatic progenitor and liver-related genes at different stages of mouse liver development

In order to isolate primary hepatic progenitor cells form liver tissue, we firstly sought to examine the expression profiles of hepatic progenitor and related markers in liver tissues 

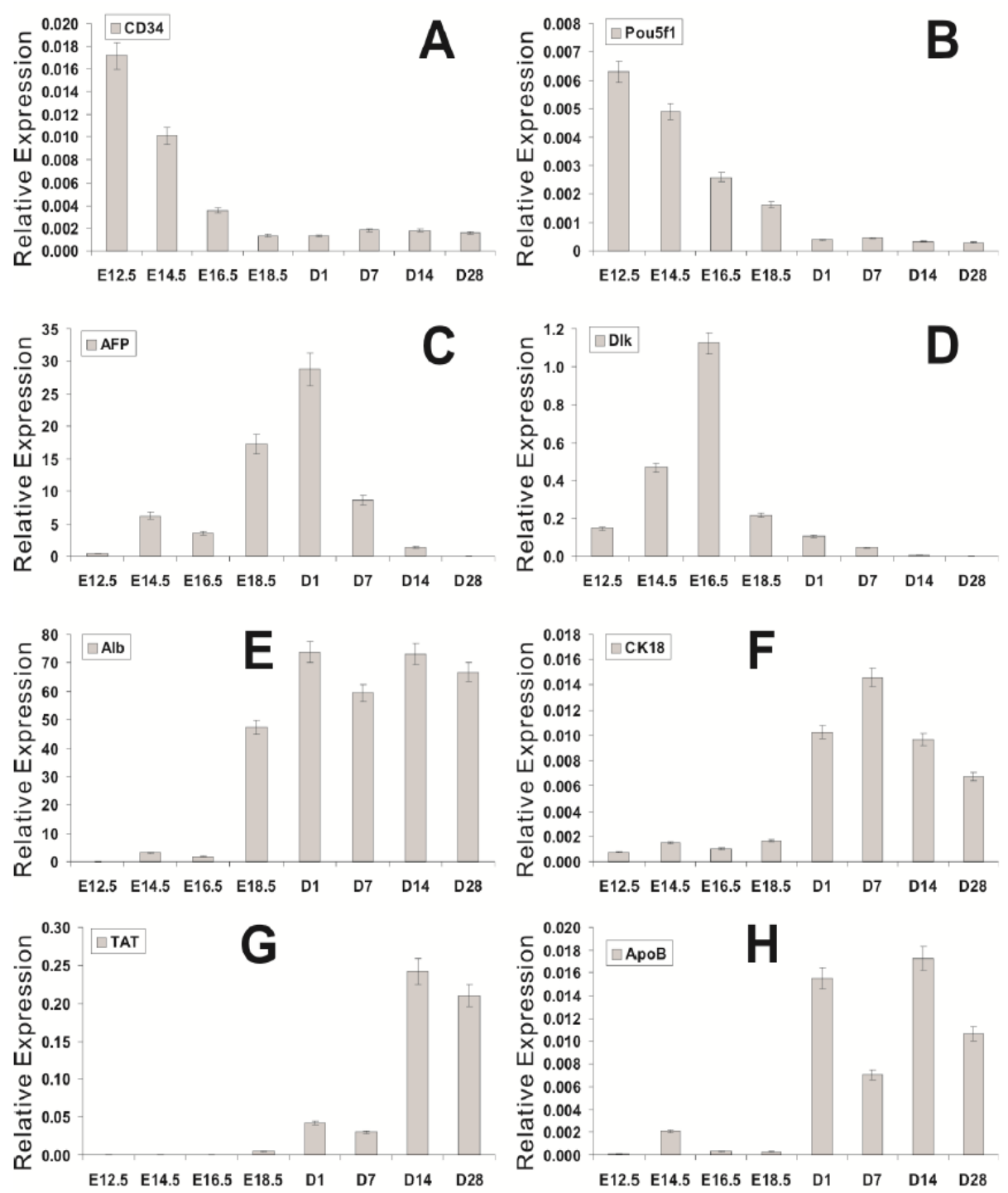

Fig. 1. Endogenous expression of hepatic progenitor and liver-related genes at different stages of mouse liver development. Total RNA was isolated from mouse liver tissues at the indicated 8 time points. The qPCR was carried out to detect the expression of endothelial progenitor cell markers CD34 (A) and Pou5f1/Oct4 (B), hepatic markers AFP (C), Dlk (D), and Alb (E), and mature hepatocyte markers CK18 (F), TAT (G), and ApoB (H). All samples were normalized with GAPDH and done in triplicate. Relative expression was calculated by dividing the qPCR value of a given gene of interested with its respective GAPDH value.

derived from different stages of liver development from post coitus day 12.5 to postnatal 4 weeks. We carried out qPCR analysis of the expression of endothelial and progenitor markers CD34 and Pou5f1/Oct4, hepatic markers AFP, Dlk, and Alb, and mature hepatocyte markers CK18, TAT, and ApoB. We found that early hepatic stem cell marker CD34 [77] and somatic stemness-related marker POU domain, class 5, transcription factor 1 (Pou5f1/ Oct4) [78] highly expressed in prenatal liver tissues and decreased quickly after birth (Fig. $1 \mathrm{~A}$ and $1 \mathrm{~B}$ ). The expression of hepatic early marker genes delta-like protein-like protein (Dlk) and alpha-fetaprotein (AFP) [79, 80] was readily detected in early liver tissues and increased to top expression at post coitus day 16.5 and postnatal day 1 , respectively, then significantly decreased in postnatal liver tissues and became undetectable in postnatal 28 
Fig. 2. Endogenous expression of hepatic/pancreatic transcription factors during mouse liver development. The qPCR analysis was carried out on the same set of samples prepared in Figure 1. The expression of HNF3 $\alpha$ /Foxa1 (A), HNF3 $\beta /$ Foxa2 (B), and HNF4 $\alpha$ /MODY1 (C) was assessed by qPCR in triplicate. Relative expression was calculated by dividing the qPCR value of a given gene of interested with its respective GAPDH value.

days (Fig. 1C and 1D). Alb and cytokeratin 18 (CK18) are considered hepatic specific markers, while tyrosine amino transferase (TAT) and apoplipoprotein B (ApoB) are synthesized by functional hepatocytes [81, 82]. These four markers had low- or nonexpression in embryonic liver tissues, but increased quickly after birth and maintained at a relatively high expression level (Fig. 1E to $1 \mathrm{H}$ ). Thus, our results suggest that the
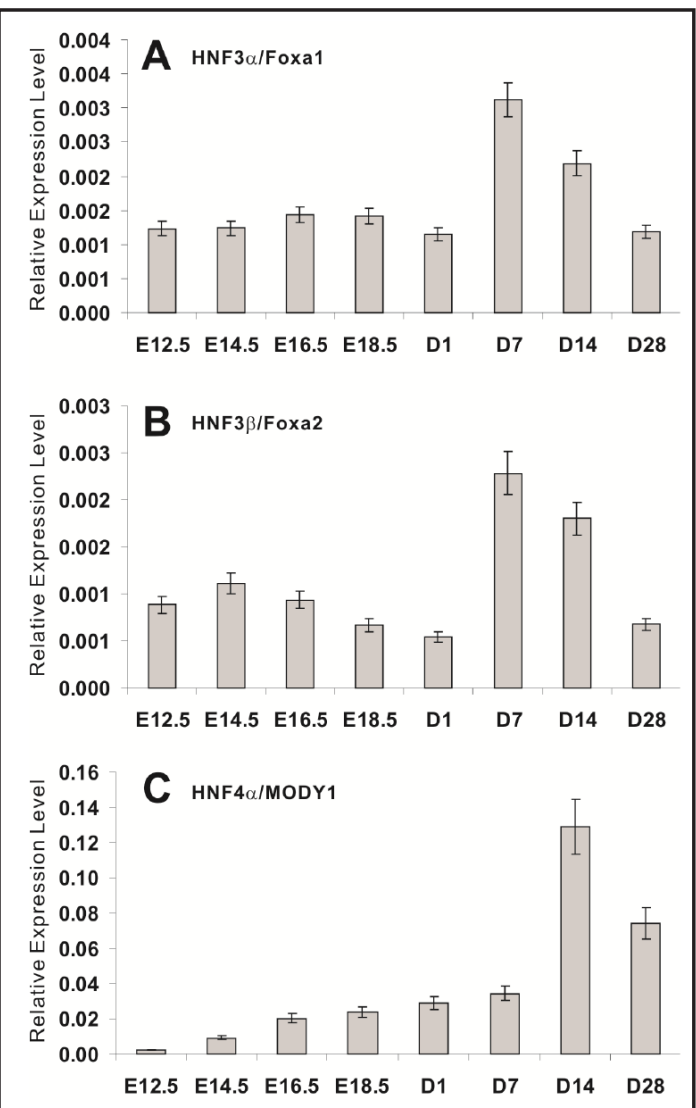
most of hepatic progenitor cells may be present in the stage prior to post coitus day 14.5.

Endogenous expression of hepatic/pancreatic transcription factors during mouse liver development

Hepatocyte nuclear factors (HNFs) are a group of phylogenetically unrelated transcription factors that regulate the transcription of a diverse group of genes, including certain genes that are important for hepatic functions, such as morphological and functional differentiation of hepatocytes, glucose transport and metabolism [83]. Among the HNFs, HNF3 $\alpha$ /Foxa1, HNF3 $\beta$ /Foxa2, and HNF4 $\alpha$ /MODY1 have been shown to play essential roles in hepatic/pancreatic/intestine development [84]. We sought to examine the expression patterns of HNF3 $\alpha$ /Foxa1, HNF3 $\beta /$ Foxa2, and HNF4 $\alpha$ /MODY1 during liver development. We found that although all three genes' expression levels varied, HNF3 $\alpha$ and HNF3 $\beta$ exhibited rather steady prenatal expression level with a postnatal spike at D7 to D14 (Fig. 2A and 2B) while HNF4 $\alpha$ /MODY1 expressed progressively higher and peaked at D14 (Fig. 2C). Interestingly, HNF4 $\alpha$ /MODY1 exhibited much higher expression than that of the HNF3 $\alpha$ / Foxa1 and HNF3 $\beta$ /Foxa2's at each tested time (Fig. 2A and 2B vs. 2C), suggesting that HNF4 $\alpha$ / MODY1 may be more abundant and play important liver-specific roles. Taken together, these results indicate that embryonic liver tissues may serve as a good source of hepatic progenitor cells that are programmed for liver-specific gene expression and differentiation.

\section{Establishment of reversibly immortalized hepatic progenitor (iHP) cell clones from mouse} fetal liver

As mouse fetal liver can't be easily identified until post coitus day 10.5, we prepared and isolated primary HP cells from mouse embryonic liver tissues of post coitus day 11.5 to 14.5. The freshly isolated primary cells could be maintained in complete DMEM culture for up to two weeks (Fig. 3A). To generate reversibly immortalized progenitor cells, we used the immortalizing retroviral SSR\#69 vector that expresses a hygromycin-resistance gene 
Fig. 3. Establishment of reversibly immortalized hepatic progenitor (iHP) cell clones from mouse fetal liver. (A) Morphology of freshly isolated HP cells. Mouse hepatic progenitor cells were isolated from the embryonic liver tissues of E11.5 to 14.5 mouse embryos. The freshly isolated primary cells could be maintained in complete DMEM culture for up to two weeks. Representative results are shown. (B) Schematic representation of the retroviral vector SSR \#69 for reversible immortalization of primary cells. The SSR \#69 vector expresses SV40 large $\mathrm{T}$ antigen and hygromycinresistance marker that are flanked with LoxP sites. (C) Establishment of immortalized HP clones. The freshly isolated primary HP cells were infected with the packaged SSR\#69 retrovirus and selected in hygromycin B $(0.3 \mathrm{mg} / \mathrm{mL}$, Invitrogen) for 7 10 day. The recovered stable pools were seeded into multiple 96-well plates using the limiting dilution cloning method. More than 60 clones derived from single cells were chosen and scaled up as immortalized HP (iHP) clones. Representative iHP clones that were maintained in complete DMEM culture are shown.
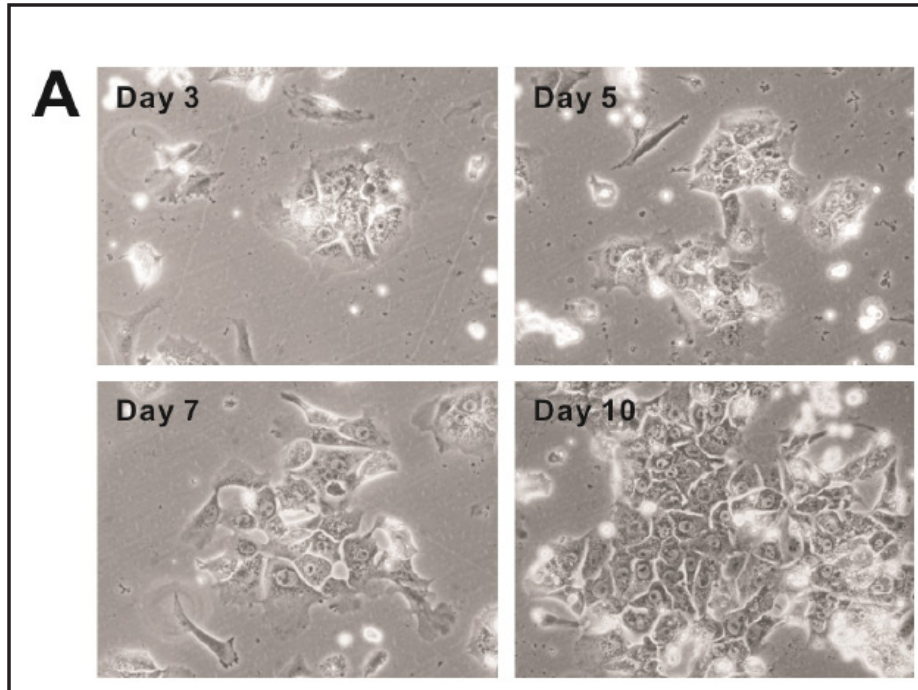

B SSR \#69

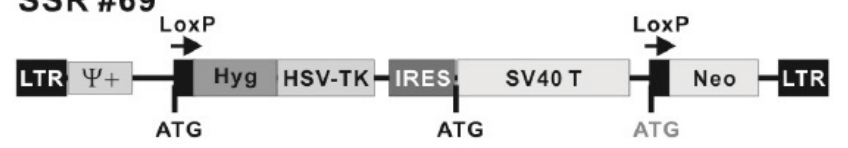

C
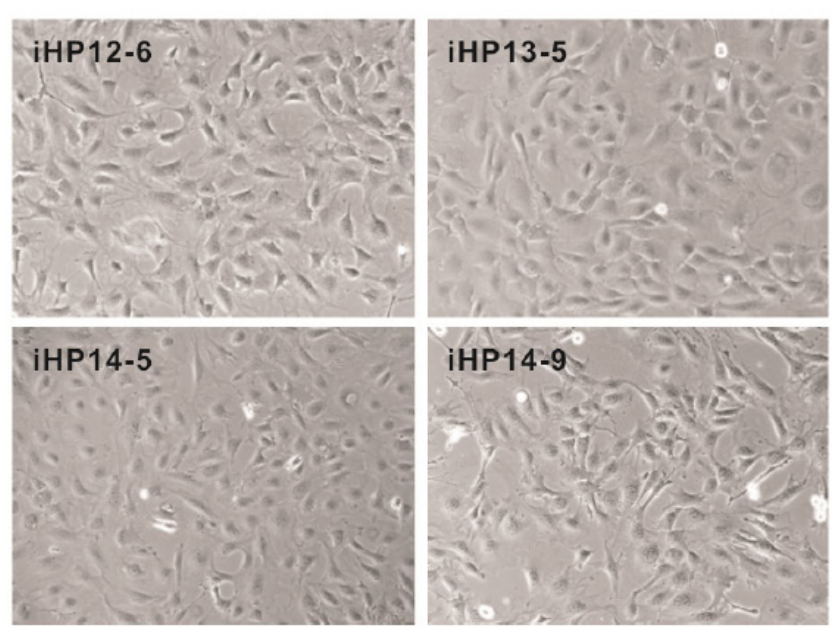

and immortalizing SV40 T antigen (Fig. 3B) [49]. We have successfully used this system and immortalized primary progenitors from various sources [50-52, 54, 62]. Accordingly, we successfully generated immortalized hepatic progenitor (iHP) cells isolated from different stages of embryonic liver tissues (Fig. 3C). Unlike primary HP cells, the iHP cells can be passaged and stable in culture for numerous generations. Thus, we demonstrate that SV40 T antigen mediated-immortalization strategy is effective to establish long-term cell culture of hepatic progenitor cells.

\section{Characterization of individual iHP clones}

As hepatic progenitor cells isolated from fetal liver tissues may contain various types of cells, such as hepatocytes, parenchymal cells, stellate cells, kupffer cells, and liver fibroblasts, we performed the limiting dilution cloning assays and identified more than 60 clones that were derived from single iHP cells. Thirty-two clones were randomly selected from further characterization by focusing on their expression levels of progenitor markers and late hepatocyte makers. When the expression of Pou5f1/Oct4 and Dlk was analyzed, we found that most iHP clones expressed these two primitive endoderm and hepatic lineage 


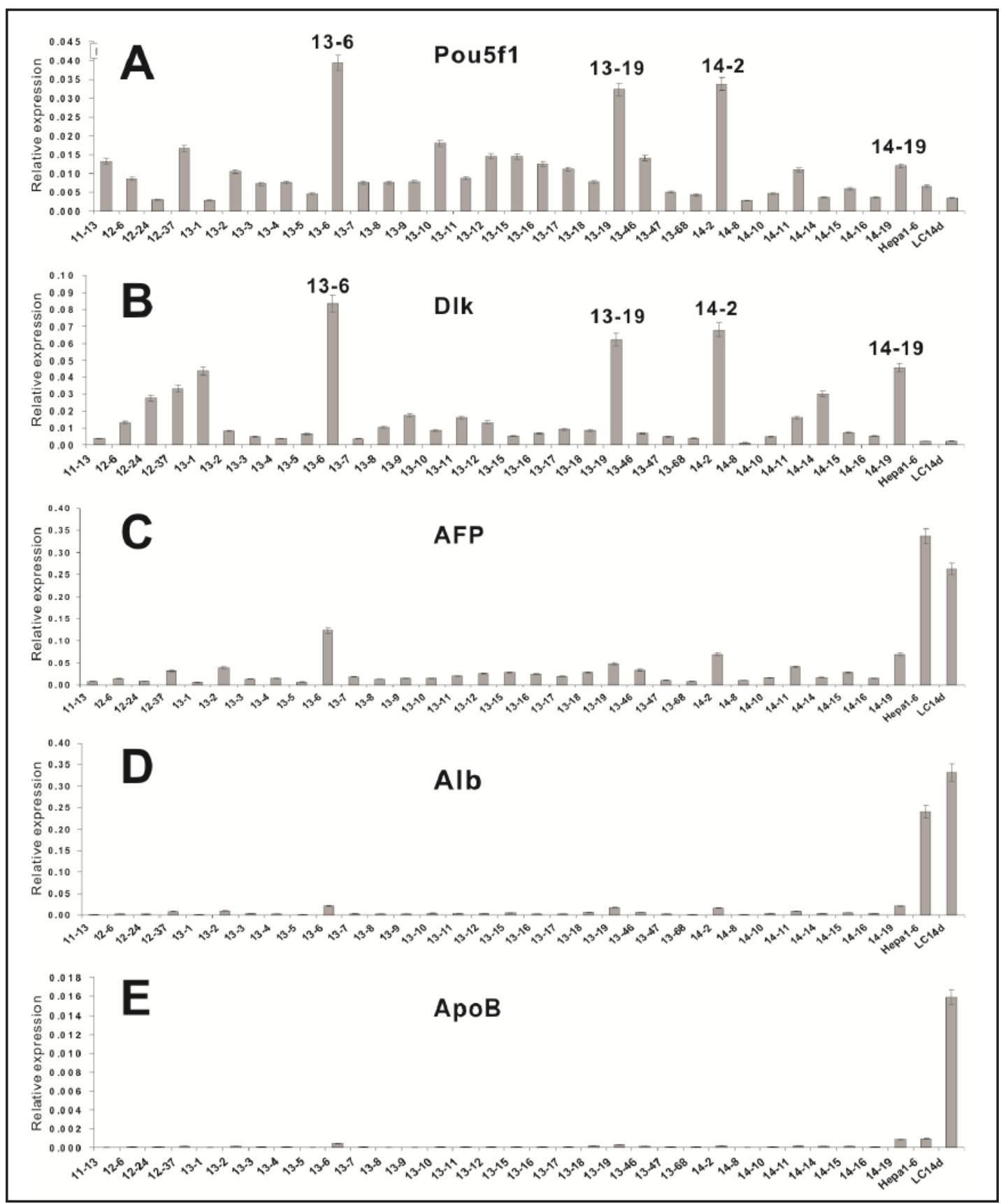

Fig. 4. Basal expression levels of the progenitor and hepatocyte markers in the iHP clones. Total RNA was isolated from $32 \mathrm{iHP}$ clones (passage 25), the mouse hepatoma line Hepa1-6, and the immortalized mouse hepatocytes (LC14d) from 14-day-old mouse liver tissues (passage 23), and subjected to reverse transcription reactions. The qPCR was performed to detect the basal expression of the progenitor cell marker Pou5f1/ Oct4 (A), hepatic related markers Dlk (B), AFP (C) and Alb (D), and the mature hepatocyte marker ApoB (E). All samples were normalized with GAPDH, and the qPCR reactions were done in triplicate. Relative expression was calculated by dividing the qPCR value of a given gene of interested with its respective GAPDH value.

progenitor markers, especially in iHP13-6, iHP13-19, iHP14-2, and iHP14-19, while the mature hepatocytes LC14d and hepatoma line Hepa1-6 expressed rather low levels of Pou5f1/Oct4 and Dlk (Fig. 4A and 4B). Hepatoblast marker AFP was highly expressed in 
the LC14d and Hepa1-6 cells, but was low in most iHP clones (except iHP13-6, iHP14-2, and iHP14-19) (Fig. 4C). Furthermore, mature hepatocyte markers Alb and ApoB exhibited very low expression levels in almost all iHP clones, but were highly expressed in LC14d and Hepa1-6 cell lines (Fig. 4D and 4E). Taken together, our results suggest that the clones iHP136, iHP13-19, iHP14-2 and iHP14-19 may represent hepatic progenitor cells.

\section{Functional characterization of representative iHP clones}

Based on the expression patterns of early progenitor markers and mature hepatocyte genes, five representative iHP clones (i.e., iHP13-6, iHP13-16, iHP13-19, iHP14-2, and iHP14-19) were selected for further functional characterizations. Morphologically, the five clones look similar although iHP14-2 adapted more fibroblast-like morphology (Fig. 5A). We further assessed the endogenous expression patterns of hepatic/pancreatic transcription factors in the selected iHP clones. The results indicated that HNF3 $\alpha / F o x a 1, H N F 3 \beta / F o x a 2$, and $H N F 4 \alpha / M O D Y 1$ genes were expressed at varied levels in the iHP clones, as well as in LC14d hepatocytes (Fig. 5B).

We next examined how the iHP cells responded to dexamethasone (Dex)-induced differentiation. When the iHP cells were treated with Dex $(0.1 \mu \mathrm{M})$ for up to 10 days, the expression levels of AFP was found increased to varied degrees in all five iHP clones with the iHP13-16 exhibited the largest increase (Fig. 5C, top panel). When the expression of late hepatocyte marker TAT was examined, all iHP clones except iHP14-2 exhibited significant increases $(p<0.05)$ (Fig. 5C). Taken together, the AFP and TAT expression results indicate that four of the five iHP clones are responsive to Dex-induced differentiation.

Since Indocyanine Green (ICG) uptake and glycogen storage are liver-specific functions associated with differentiated hepatocytes in vitro [85], we examined whether the iHP clones had these capabilities upon Dex-induced differentiation. In the ICG uptake assay, we found that, although all clones exhibited some background ICG uptake, a significant increase in ICG uptake was observed in all five iHP clones while hepatoma Hepa1-6 cells did not exhibit any significant increase in ICG uptake upon Dex treatment (Fig. 5D, and data now shown). The glycogen storage capabilities were assessed by using the Periodic Acid-Schiff (PAS) staining. Upon Dex stimulation, all iHP clones exhibited varied levels of increase in PAS staining while the iHP13-16 and iHP14-2 clones were significantly stained at lower levels (Fig. 5E, and data not shown). Taken together, the above results indicate the selected five iHP clones retain the potential to undergo liver-specific terminal differentiation although there are discernable clonal variations in the differentiation efficiencies.

Cre-mediated reversal of immortalization reduces cell proliferative activity and improves hepatic differentiation of the iHP cells

As indicated in the SSR \#69 vector (Fig. 3B), the expression of SV40 T antigen in the iHP cells can be removed and thus may lead to the reversal of the immortalization process. We used a recombinant adenovirus expressing Cre recombinase (Ad-Cre) to transduce iHP cells, and the effective removal of SV40 T antigen was confirmed by Western blotting analysis using an SV40 T antibody (Fig. 6A). When the SV40 T antigen was removed from the iHP cells, the Cre-expressing iHP cells grew at a significantly slower rate than that of the GFPexpressing iHP cells at all tested time points $(\mathrm{p}<0.05)$ (Fig. 6B). As expected, the growth rate of the control Hepa1-6 cells was not affected. Thus, these results indicate that the SV40 T antigen-mediated immortalization of hepatic progenitor cells is reversible.

It has been reported a stable expression of SV40 T antigen may inhibit terminal differentiation of some cell types, such as skeletal muscle cells, myoblasts, and adipocytes [86]. We sought to test if the SV40 T antigen-mediated immortalization would inhibit the terminal differentiation of the iHP cells. Using the iHP14-19 cells transduced with Alb-GLuc reporter as an example, we found that the iHP14-19 cells were still able to differentiate (reflected by the increased Alb-GLuc activities) upon Dex stimulation in the presence of SV40 T antigen ( $p<0.05$ ) (Fig. 6C). We further found that Cre-mediated removal of SV40 T antigen led to increased Alb-GLuc activities of the iHP14-19 cells, compared with that of the 
Fig. 5. Functional characterization of five representative iHP clones. (A) Morphological presentation of the five iHP clones, which were selected on the basis of their expression of the progenitor markers and late-stage markers assessed in Figure 4. (B) Basal expression of hepatic/pancreatic transcription factors in the selected iHP clones. Total RNA was isolated from the five iHP clones (passage 28) and the control LC14d cells (passage 27), and subjected to RT-PCR. The basal expression of HNF3 $\alpha$ /Foxa1, HNF33/ Foxa2, and HNF4 $\alpha$ / MODY1 genes was assessed by semi-quantitative RT-PCR. GAPDH was used an internal control. Representative results are shown. (C) Dexamethasone (Dex) induced differentiation of the iHP cells. Subconfluent iHP cells were treated with Dex $(0.1 \mu \mathrm{M})$ or DMSO. RNA was isolated at days 5 and 10 , and subjected to qPCR analysis to detect the expression of AFP and TAT. All samples were normalized by

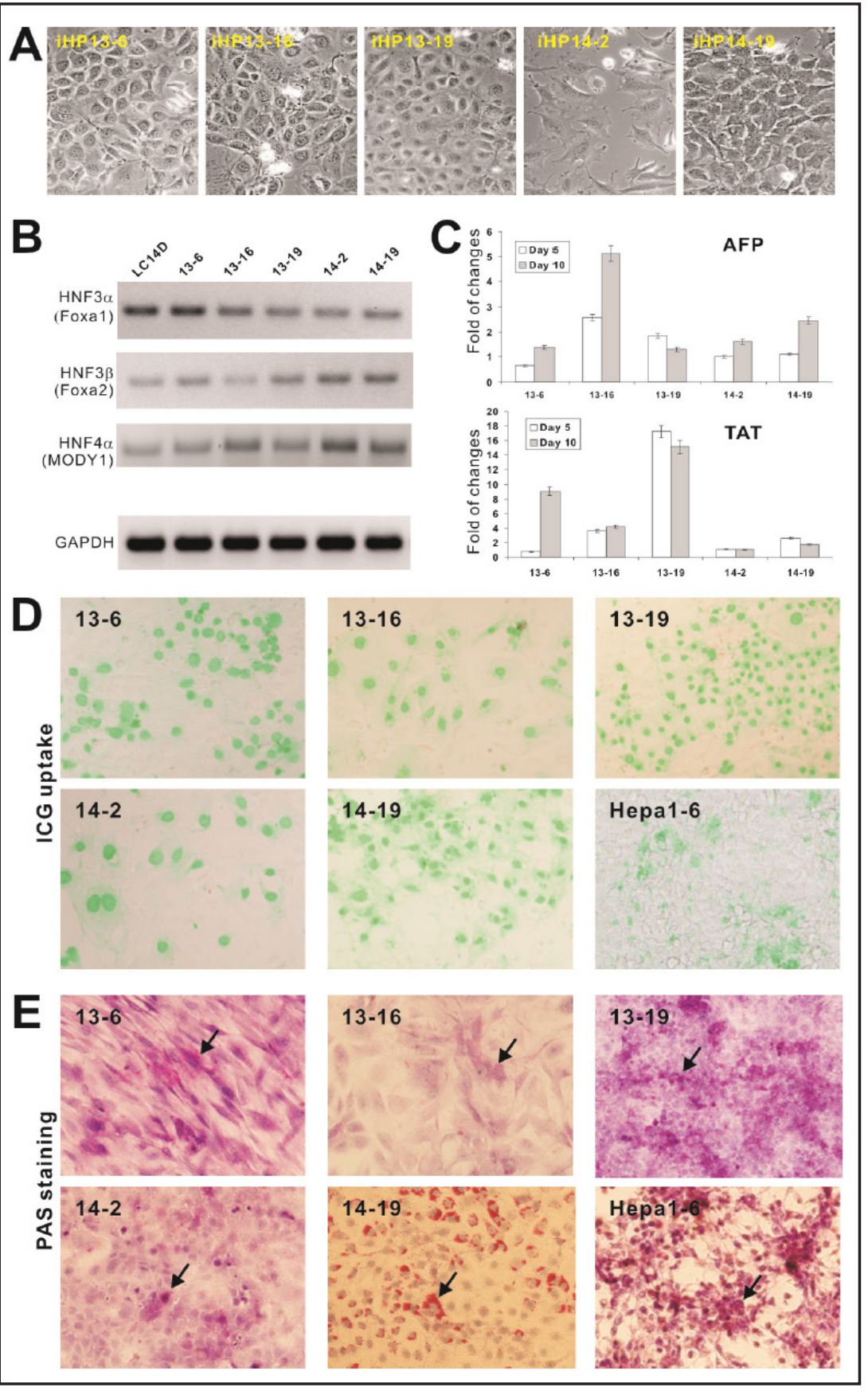
GAPDH expression level. Fold of changes was calculated by dividing the qPCR expression values from the Dex treatment group by that from the respective DMSO control group. (D) Dex-induced Indocyanine Green (ICG) uptake assay. Subconfluent iHP cells were treated with Dex $(0.1 \mu \mathrm{M})$ or DMSO for 10 days. Cells were washed with PBS and incubated with ICG $\left(1 \mathrm{mg} / \mathrm{mL}\right.$ in complete DMEM) at $37^{\circ} \mathrm{C}$ for $1 \mathrm{~h}$, followed by PBS washes. ICG uptake was observed and recorded under bright field. Significantly lower ICG uptake in the DMSO treatment groups was detected (data not shown). Each assay condition was done in triplicate. Representative results are shown. (E) PAS staining for glycogen storage. Subconfluent iHP cells were treated with Dex $(0.1 \mu \mathrm{M})$ or DMSO for 10 days. Cells were fixed with $4 \%$ paraformaldehyde, followed by stained with $0.5 \%$ periodic acid solution and the Schiff's reagent, and counterstained with hematoxylin. PAS staining was observed and recorded under bright field. Positive stainings are indicated by arrows. Significantly lower PAS staining in the DMSO treatment groups was observed (data not shown). Each assay condition was done in triplicate. Representative results are shown. 
Fig. 6. Cre-mediated removal of SV40 $\mathrm{T}$ antigen leads to the decreased proliferative capability of the iHP cells. (A) Efficient removal of SV40 T antigen by Cre recombinase. Subconfluent iHP cells (passage 31) or control Hepa1-6 cells were infected with Ad-GFP (- lane) or Ad-Cre (+ lane) for 48h. Cell lysate was collected and subjected to Western blotting analysis using SV40 T or $\beta$-actin antibody (Santa Cruz Biotechnology). (B) Removal of SV40 $\mathrm{T}$ antigen inhibits iHP cell proliferation. The iHP lines and control Hepa1-6 cells were infected with Ad-GFP or Ad-Cre. Cells were collected and stained with trypan blue at the indicated time points. Viable cells were counted in triplicate. * $p<0.05$, ** $p<0.01$. (C) Removal of SV40 $\mathrm{T}$ antigen improves hepatic differentiation of the iHP cells. Subconfluent iHP1419 cells were transfected with pAlb-GLuc reporter plasmid and infected with Ad-GFP or Ad-Cre, followed by addition of Dex (0.1 $\mu \mathrm{M}$ ) or DMSO. At the indicated time points, Gaussia luciferase activity (mean \pm SD) was assayed. Each assay condition was performed in triplicate. Except at day 1 data points, $p<0.05$, Dex treatment vs. DMSO treatment

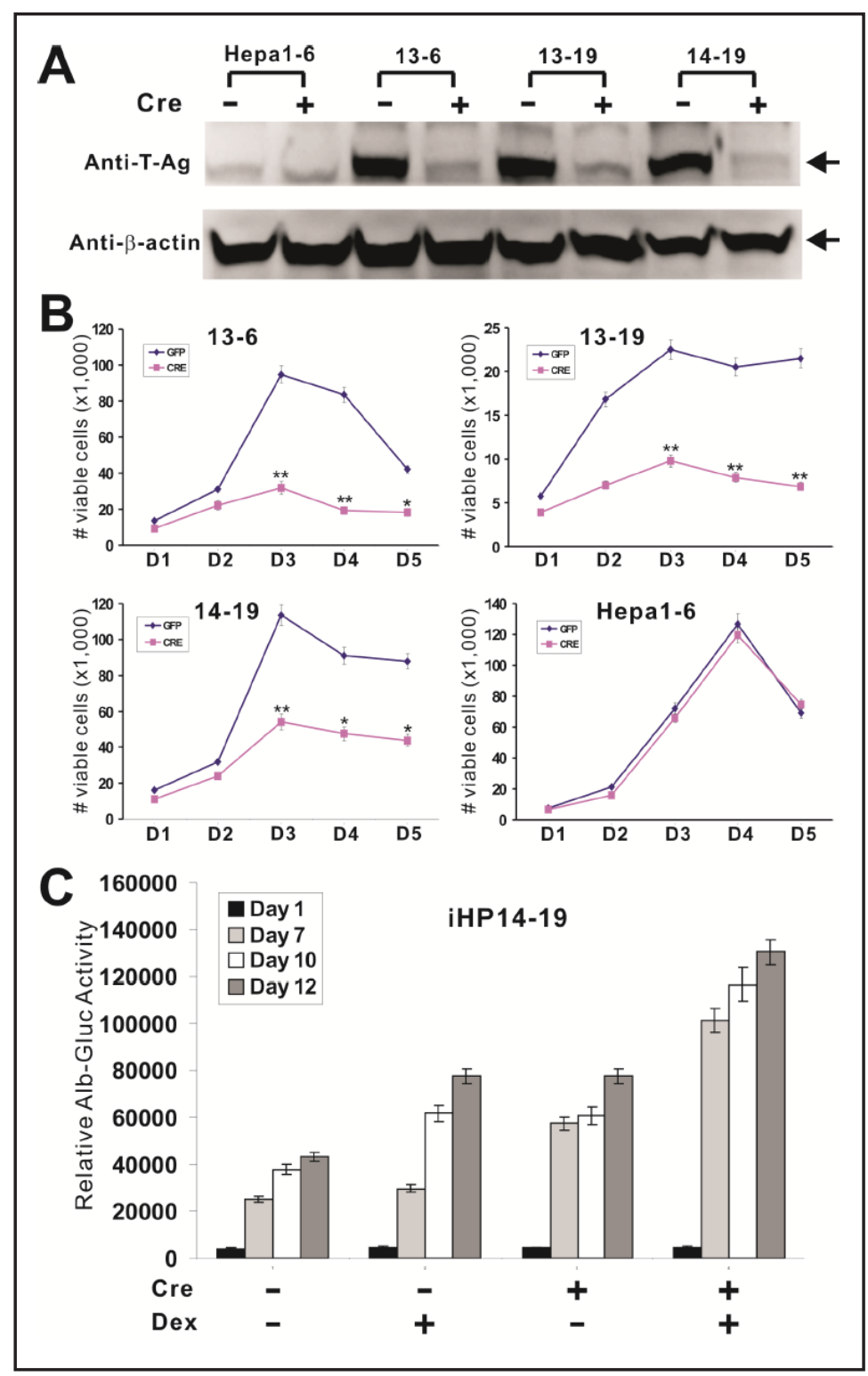
in Ad-GFP groups; $p<0.001$, Dex treatment vs. DMSO treatment in Ad-Cre groups; $p<0.05$, Ad-Cre vs. Ad-GFP in DMSO treatment groups; $p<0.001$, Ad-Cre vs. Ad-GFP in Dex treatment groups.

GFP-infected iHP control groups'. However, the removal of SV40 T antigen also increased the spontaneous differentiation of the iHP cells (Fig. 6C). Nonetheless, the above results indicate that the immortalized phenotypes of the iHP cells can be effectively reversed by the introduction of Cre recombinase, and that SV40 T antigen-mediated immortalization exerts minimal inhibitory effect on terminal differentiation of the iHP cells.

The iHP cells are not tumorigenic in athymic nude mice

SV40 T antigen can stimulate cell proliferation and may increase the risk of tumorigenesis in vivo [87]. We sought to test if the iHP cells had tendency to proliferate and form tumors in vivo, and if so whether the process can be reversed by Cre combinase. We first infected three iHP cells and control Hepa1-6 cells with Ad-Cre or Ad-GFP for 24h (Fig. 7A). The transduced cells were harvested and subcutaneously injected into athymic nude mice. The animals were subjected to whole body live bioluminescence imaging using Xenogen IVIS 200 at day 1, week 1, and week 2 post cell implantation. At day 1, bioluminescence signal was readily 


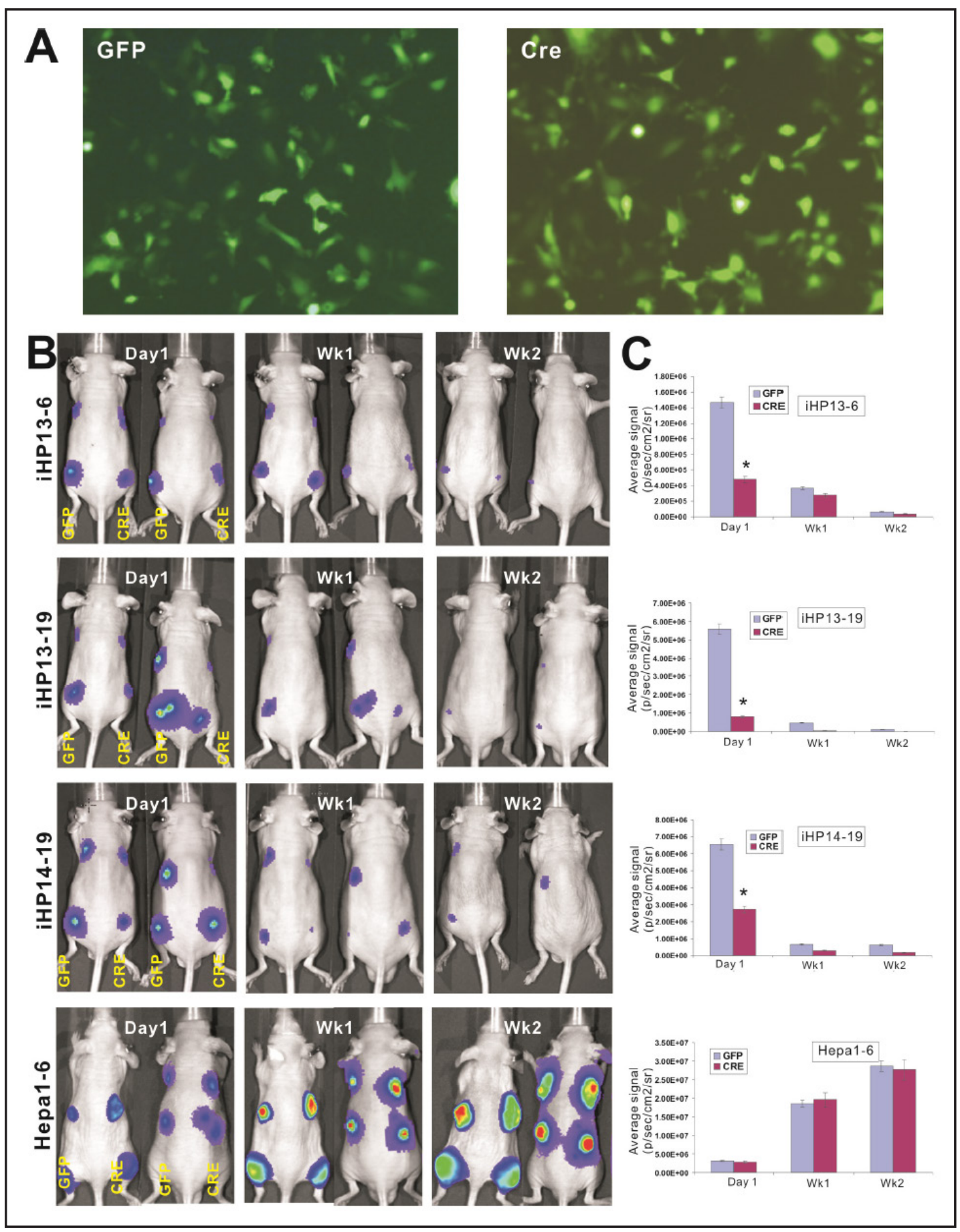

Fig. 7. The SV40 T antigen-immortalized hepatic progenitors are not tumorigenic in vivo. (A) Adenovirusmediated efficient transduction of iHP cells. Subconfluent iHP cells (passage 35) were co-infected with the same titer (multiplicity of infection MOI = 20) of Ad-Fluc and Ad-GFP or Ad-Cre. The GFP signal was examined at $24 \mathrm{~h}$ post infection. Representative results from the transduced iHP13-6 cells are shown. (B) Xenogen bioluminescence imaging of the subcutaneous growth of the transduced iHPs and Hepa1-6 cells in athymic nude mice. The above adenovirus-transduced cells (A) were collected at $24 \mathrm{~h}$ post infection and subcutaneously injected into athymic nude mice as described in the Methods. The animals were subjected to Xenogen IVIS 200 imaging at the indicated time points. Representative results are shown. (C) Quantitative analysis of the luciferase signals was conducted by using the Living Image software. ${ }^{*} p<0.05$ when compared with the GFP group at the corresponding time points. 
detected in all injected animals, while the signal was found significantly decreased in the three iHP cell-injected animals at 1 -week time point, and almost completely disappeared at 2-week time point (Fig. 7B). On the contrary, the signal in the Hepa1-6 group progressively increased over the two week period (Fig. 7B). As expected, Cre-transduced iHP cells yielded significantly lower signal than that of the GFP-transduced controls at as early as day 1 time point $(\mathrm{p}<0.05)$, while Hepa1-6 cells were not affected by Cre transduction (Fig. 7C). In addition to imaging, we continued to monitor the animals for up to 8 weeks and did not observe any tumor-like masses grown at the iHP cell injection sites. Taken together, these results demonstrate that the tested iHP cells are not tumorigenic, and that Cre-mediated removal of SV40 T antigen inhibits iHP cell proliferation in vivo.

\section{Discussion}

Although the true identity and features of liver stem cells remains to be fully understood, it is commonly accepted that hepatic progenitor cells are common progenitors of mature hepatocytes and biliary epithelial cells and act as the major component of the hepatic parenchyma in early liver development [40, 41, 88-90]. Thus, it is desirable to establish stable hepatic progenitor cells, which are non-tumorigenic and maintain the stem cell properties, as these cells provide a unique system to study stem cell regulation and to optimize conditions for directing endogenous regenerative potential towards a lineage-specific differentiation.

To overcome the limited life span of culturing primary hepatic progenitors, we established the reversibly immortalized hepatic progenitor (iHP) cells from mouse fetal liver tissues by stably expressing SV40 T antigen. A collection of individual iHP clones represents a repertoire of hepatic progenitor clones with varied differentiation potential. The iHP cells maintain long-term proliferative activity and express progenitor markers (Pou5f1/Oct4 and Dlk) and hepatocyte-related markers (HNF3 /Foxa1, HNF3 $\beta /$ Foxa2, and HNF4 $\alpha$ /MODY1). Upon dexamethasone (Dex) stimulation, the iHP cells are able to express hepatocyte markers (AFP and TAT) and perform Indocyanine Green (ICG) -uptake and glycogen storage (PAS staining) functions. Cre recombinasemediated removal of SV40 T antigen reverses the proliferative activity of the iHP cells. When the iHP cells are subcutaneously implanted in the athymic nude mice, no tumor formation is observed for up to 8 weeks. Therefore, our results demonstrate that the established iHP cells are stable, reversible, and non-tumorigenic progenitor-like cells, which should be useful for studying liver stem cell biology, liver organogenesis and developing potential cell sources/ factors for hepatocyte transplantation therapy.

It has been widely reported that hepatocytes can be derived from embryonic stem cells, mesenchymal stem cells, and iPS cells [13-28]. While these progenitor/stem cells are potentially important sources for hepatocyte transplantation, the lineage-specificity and differentiation efficiency of these progenitor cells remain to be fully characterized in vivo. This matter is further complicated by our current lack of the knowledge and understanding of the detailed mechanism through which hepatic progenitors are regulated and directed to hepatocyte lineage-specific differentiation. Thus, liver progenitor cells isolated from both fetal and adult liver tissues should have the inherited advantages over those extrahepatic sources of stem cells [1,21,29-36].

Although it has been reported that relatively long-term culturing of liver progenitor cells can be achieved under special culture conditions [31, 37-39], the primary progenitor cells usually have limited life span when maintained in vitro $[40,41]$. Several earlier studies reported the generation of progenitor lines from liver. Bipotential cell lines (so-called palmate cell lines) were established from the liver tissues of transgenic mice expressing constitutively active human Met $[91,92]$. Bipotential clonal cell lines in hepatocyte-enriched suspension culture were established from healthy liver of 8-10-week-old C57BL/6 mice [93]. Bipotential mouse embryonic liver (BMEL) cell lines were established from E14 embryos using Matrigel aggregate culture approach [30]. Stem-like cell lines were established from adult rat liver 
although the long-term culture nature of these lines were unclear[94]. Interestingly, longterm cultivation of subpopulations of non-parenchymal cells derived from non-injured livers were obtained using fetal liver cell-derived conditioned medium in the presence of the Rhoassociated kinase (ROCK) inhibitor Y-27632 [95]. Using the approach similar to what we reported here, epithelial liver stem cell lines were obtained from primate fetal liver tissues $[96,97]$. Furthermore, it was reported that progenitor cells can be isolated from human adult livers using Thy- 1 as a sorting marker and may be a potential candidate cell source for cell treatment in liver diseases [98].

Immortalization of primary cells has long been a practice for obtaining stable cell lines. The classical BALB/3T3 protocol proved the principle of cell immortalization [99] although this approach is not efficient and thus often replaced by the overexpression of oncogenes and/or the inactivation of tumor suppressor genes [100]. Many genes have been used to immortalize primary cells. The commonly-used oncogenes include telomerase (TERT), Kras, c-Myc, CDK4, cyclin D1, Bmi-1, and HPV 16 E6/E7, while the frequently inactivated tumor suppressor genes are p53, Rb, and p16 ${ }^{\mathrm{INK}}$. Here, we employed SV40 T antigen, one of the most commonly used immortalization genes [101], which plays essential roles in the infection of permissive cells, leading to production of progeny SV40 virions, and in the infection of nonpermissive cells, leading to malignant transformation $[102,103]$. The ability of SV40 large $\mathrm{T}$ antigen to immortalize primary cells may be largely dependent on its ability to complex with p53 [104]. Using the reversible immortalization system expressing SV40 T antigen [49], we have immortalized several types of progenitors and adult cells, including MEFs, mouse cardiomyogenic progenitor cells, mouse articular chondrocytes, stem cells of dental apical papilla, and mouse melanoblastic progenitor cells [50-54]. More recently, we demonstrate that piggyBac transposon-mediated stable expression of SV40 T antigen is a more efficient approach to the immortalizing primary cells [60]. The most noteworthy features shared by all of the SV40 T antigen-immortalized cells include that 1 ) they are reversible and become mortal upon the removal of SV40 T antigen from the immortalized cells; 2) stable expression of SV40 $\mathrm{T}$ antigen does not completely inhibit the differentiation potential although the removal of SV40 T antigen has been shown to improve the terminal differentiation; and 3) the immortalized cells are non-tumorigenic in immune compromised mice, even after an extended observation period [50-52, 54].

In summary, we sought to overcome the mortality of primary hepatic progenitor cells in vitro, and established the reversibly immortalized hepatic progenitor (iHP) cells from mouse fetal liver tissues by stably expressing SV40 T antigen. More than 60 iHP clones were obtained. Among 32 clones were analyzed. We found the iHP cells maintain long-term proliferative activity and express progenitor markers and hepatocyte-related markers. Upon the induction of differentiation, the iHP cells are able to express mature hepatocyte markers and perform ICG uptake and glycogen storage functions. Removal of SV40 T antigen can reverse iHP cell proliferative activity. When the iHP cells were subcutaneously implanted in the athymic nude mice, no tumor formation is observed for up to 8 weeks. Therefore, our results demonstrate that the established iHP cells are stable, reversible, and nontumorigenic progenitor-like cells. The iHP cells should be a valuable resource for studying stem cell biology, liver organogenesis, hepatic tumorigenesis, and metabolic regulations, and identifying factors involved in directed lineage-specific differentiation for potential hepatocyte transplantation as a treatment of liver diseases.

\section{Acknowledgements}

The authors wish to thank Dr. Philippe Leboulch of Harvard Medical School for the generous provision of SSR \#69 vector. The authors also thank Dr. Linda Degenstein of The University of Chicago Transgenic Core Facility for providing technical support for the timed pregnant mice for the HP cell preparations. The reported work was supported in part by research grants from the National Institutes of Health (AT004418, AR50142, and AR054381 
to TCH, RCH and HHL), the National Natural Science Foundation of China (\#81100309 to YB; \#81371827, \#31171307 to NT), the Natural Science Foundation Project of Chongqing (NT), the Key National S \& T Program of China (2013ZX10002002-005-003 to NT; 2012ZX10002005-003-002 to NT). This work was also supported in part by The University of Chicago Core Facility Subsidy grant from the National Center for Advancing Translational Sciences (NCATS) of the National Institutes of Health through Grant Number UL1 TR000430. The funders had no role in study design, data collection and analysis, decision to publish, or preparation of the manuscript.

\section{Disclosure Statement}

The authors declare no conflict of interest.

\section{References}

1 Miyajima A, Tanaka M, Itoh T: Stem/progenitor cells in liver development, homeostasis, regeneration, and reprogramming. Cell Stem Cell 2014;14:561-574.

2 Duncan AW, Dorrell C, Grompe M: Stem cells and liver regeneration. Gastroenterology 2009;137:466-481.

3 Alison MR, Choong C, Lim S: Application of liver stem cells for cell therapy. Semin Cell Dev Biol 2007;18:819-826.

4 Samuel D, Colombo M, El-Serag H, Sobesky R, Heaton N: Toward optimizing the indications for orthotopic liver transplantation in hepatocellular carcinoma. Liver Transpl 2011;17:S6-13.

-5 Adam R, Hoti E: Liver transplantation: The current situation. Semin Liver Dis 2009;29:3-18.

6 Russo FP, Parola M: Stem and progenitor cells in liver regeneration and repair. Cytotherapy 2011;13:135144.

7 Souza BS, Nogueira RC, de Oliveira SA, de Freitas LA, Lyra LG, Ribeiro dos Santos R, Lyra AC, Soares MB: Current status of stem cell therapy for liver diseases. Cell Transplant 2009;18:1261-1279.

8 Dhawan A, Mitry RR, Hughes RD: Hepatocyte transplantation for liver-based metabolic disorders. J Inherit Metab Dis 2006;29:431-435.

-9 Quaglia A, Lehec SC, Hughes RD, Mitry RR, Knisely AS, Devereaux S, Richards J, Rela M, Heaton ND, Portmann BC, Dhawan A: Liver after hepatocyte transplantation for liver-based metabolic disorders in children. Cell Transplant 2008;17:1403-1414.

10 Hughes RD, Mitry RR, Dhawan A: Current status of hepatocyte transplantation. Transplantation 2011;93:342-347.

11 Kisseleva T, Gigante E, Brenner DA: Recent advances in liver stem cell therapy. Curr Opin Gastroenterol 2010;26:395-402.

12 Tremblay KD, Zaret KS: Distinct populations of endoderm cells converge to generate the embryonic liver bud and ventral foregut tissues. Developmental biology 2005;280:87-99.

13 Si-Tayeb K, Noto FK, Nagaoka M, Li J, Battle MA, Duris C, North PE, Dalton S, Duncan SA: Highly efficient generation of human hepatocyte-like cells from induced pluripotent stem cells. Hepatology (Baltimore, Md 2010;51:297-305.

-14 Ogawa S, Surapisitchat J, Virtanen C, Ogawa M, Niapour M, Sugamori KS, Wang S, Tamblyn L, Guillemette C, Hoffmann E, Zhao B, Strom S, Laposa RR, Tyndale RF, Grant DM, Keller G: Three-dimensional culture and camp signaling promote the maturation of human pluripotent stem cell-derived hepatocytes. Development (Cambridge, England) 2013;140:3285-3296.

15 Rashid ST, Corbineau S, Hannan N, Marciniak SJ, Miranda E, Alexander G, Huang-Doran I, Griffin J, AhrlundRichter L, Skepper J, Semple R, Weber A, Lomas DA, Vallier L: Modeling inherited metabolic disorders of the liver using human induced pluripotent stem cells. J Clin Invest 2010;120:3127-3136.

16 Yusa K, Rashid ST, Strick-Marchand H, Varela I, Liu PQ, Paschon DE, Miranda E, Ordonez A, Hannan NR, Rouhani FJ, Darche S, Alexander G, Marciniak SJ, Fusaki N, Hasegawa M, Holmes MC, Di Santo JP, Lomas DA, Bradley A, Vallier L: Targeted gene correction of alpha1-antitrypsin deficiency in induced pluripotent stem cells. Nature 2011;478:391-394. 
17 Yanagida A, Ito K, Chikada H, Nakauchi H, Kamiya A: An in vitro expansion system for generation of human ips cell-derived hepatic progenitor-like cells exhibiting a bipotent differentiation potential. PloS One 2013;8:e67541.

18 Zhao D, Chen S, Cai J, Guo Y, Song Z, Che J, Liu C, Wu C, Ding M, Deng H: Derivation and characterization of hepatic progenitor cells from human embryonic stem cells. PloS One 2009;4:e6468.

19 Zhu S, Rezvani M, Harbell J, Mattis AN, Wolfe AR, Benet LZ, Willenbring H, Ding S: Mouse liver repopulation with hepatocytes generated from human fibroblasts. Nature 2014;508:93-97.

20 Takebe T, Sekine K, Enomura M, Koike H, Kimura M, Ogaeri T, Zhang RR, Ueno Y, Zheng YW, Koike N, Aoyama S, Adachi Y, Taniguchi H: Vascularized and functional human liver from an ipsc-derived organ bud transplant. Nature 2013;499:481-484.

-21 Goldman O, Han S, Sourrisseau M, Dziedzic N, Hamou W, Corneo B, D'Souza S, Sato T, Kotton DN, Bissig KD, Kalir T, Jacobs A, Evans T, Evans MJ, Gouon-Evans V: Kdr identifies a conserved human and murine hepatic progenitor and instructs early liver development. Cell Stem Cell 2013;12:748-760.

22 Banas A, Teratani T, Yamamoto Y, Tokuhara M, Takeshita F, Quinn G, Okochi H, Ochiya T: Adipose tissue-derived mesenchymal stem cells as a source of human hepatocytes. Hepatology (Baltimore, Md 2007;46:219-228.

23 Lee KD, Kuo TK, Whang-Peng J, Chung YF, Lin CT, Chou SH, Chen JR, Chen YP, Lee OK: In vitro hepatic differentiation of human mesenchymal stem cells. Hepatology (Baltimore, Md 2004;40:1275-1284.

24 Sekiya S, Suzuki A: Direct conversion of mouse fibroblasts to hepatocyte-like cells by defined factors. Nature 2011;475:390-393.

25 Huang P, He Z, Ji S, Sun H, Xiang D, Liu C, Hu Y, Wang X, Hui L: Induction of functional hepatocyte-like cells from mouse fibroblasts by defined factors. Nature 2011;475:386-389.

26 Du Y, Wang J, Jia J, Song N, Xiang C, Xu J, Hou Z, Su X, Liu B, Jiang T, Zhao D, Sun Y, Shu J, Guo Q, Yin M, Sun D, Lu S, Shi Y, Deng H: Human hepatocytes with drug metabolic function induced from fibroblasts by lineage reprogramming. Cell Stem Cell 2014;14:394-403.

27 Yu B, He ZY, You P, Han QW, Xiang D, Chen F, Wang MJ, Liu CC, Lin XW, Borjigin U, Zi XY, Li JX, Zhu HY, Li WL, Han CS, Wangensteen KJ, Shi Y, Hui LJ, Wang X, Hu YP: Reprogramming fibroblasts into bipotential hepatic stem cells by defined factors. Cell Stem Cell 2013;13:328-340.

28 Li F, Liu P, Liu C, Xiang D, Deng L, Li W, Wangensteen K, Song J, Ma Y, Hui L, Wei L, Li L, Ding X, Hu Y, He Z, Wang X: Hepatoblast-like progenitor cells derived from embryonic stem cells can repopulate livers of mice. Gastroenterology 2010;139:2158-2169 e2158.

29 Tanimizu N, Saito H, Mostov K, Miyajima A: Long-term culture of hepatic progenitors derived from mouse dlk+ hepatoblasts. J Cell Sci 2004;117:6425-6434.

-30 Strick-Marchand H, Weiss MC: Inducible differentiation and morphogenesis of bipotential liver cell lines from wild-type mouse embryos. Hepatology (Baltimore, Md 2002;36:794-804.

-31 Tsuchiya A, Heike T, Fujino H, Shiota M, Umeda K, Yoshimoto M, Matsuda Y, Ichida T, Aoyagi Y, Nakahata T: Long-term extensive expansion of mouse hepatic stem/progenitor cells in a novel serum-free culture system. Gastroenterology 2005;128:2089-2104.

-32 Dan YY, Riehle KJ, Lazaro C, Teoh N, Haque J, Campbell JS, Fausto N: Isolation of multipotent progenitor cells from human fetal liver capable of differentiating into liver and mesenchymal lineages. Proc Natl Acad Sci USA 2006;103:9912-9917.

-33 Schmelzer E, Zhang L, Bruce A, Wauthier E, Ludlow J, Yao HL, Moss N, Melhem A, McClelland R, Turner W, Kulik M, Sherwood S, Tallheden T, Cheng N, Furth ME, Reid LM: Human hepatic stem cells from fetal and postnatal donors. J Exp Med 2007;204:1973-1987.

34 Magami Y, Azuma T, Inokuchi H, Kokuno S, Moriyasu F, Kawai K, Hattori T: Cell proliferation and renewal of normal hepatocytes and bile duct cells in adult mouse liver. Liver 2002;22:419-425.

35 Sangan CB, Tosh D: Hepatic progenitor cells. Cell Tissue Res 2010;342:131-137.

-36 Kakinuma S, Nakauchi H, Watanabe M: Hepatic stem/progenitor cells and stem-cell transplantation for the treatment of liver disease. J Gastroenterol 2009;44:167-172.

37 Tsuchiya A, Heike T, Baba S, Fujino H, Umeda K, Matsuda Y, Nomoto M, Ichida T, Aoyagi Y, Nakahata T: Longterm culture of postnatal mouse hepatic stem/progenitor cells and their relative developmental hierarchy. Stem Cells (Dayton, Ohio) 2007;25:895-902.

-38 Begum S, Joshi M, Ek M, Holgersson J, Kleman MI, Sumitran-Holgersson S: Characterization and engraftment of long-term serum-free human fetal liver cell cultures. Cytotherapy 2010;12:201-211. 
39 Sasaki K, Kon J, Mizuguchi T, Chen Q Ooe H, Oshima H, Hirata K, Mitaka T: Proliferation of hepatocyte progenitor cells isolated from adult human livers in serum-free medium. Cell Transplant 2008;17:12211230.

40 Zhang W, Li W, Liu B, Wang P, Zhang H: Efficient generation of functional hepatocyte-like cells from human fetal hepatic progenitor cells in vitro. J Cell Physiol 2012;227:2051-2058.

41 Schwartz RE, Verfaillie C: Hepatic stem cells. Methods Mol Biol 2010;640:167-179.

42 Kong Y, Zhang H, Chen X, Zhang W, Zhao C, Wang N, Wu N, He Y, Nan G, Zhang H, Wen S, Deng F, Liao Z, Wu D, Zhang J, Qin X, Haydon RC, Luu HH, He TC, Zhou L: Destabilization of heterologous proteins mediated by the gsk3beta phosphorylation domain of the beta-catenin protein. Cell Physiol Biochem 2013;32:11871199.

43 Chen X, Luther G, Zhang W, Nan G, Wagner ER, Liao Z, Wu N, Zhang H, Wang N, Wen S, He Y, Deng F, Zhang J, Wu D, Zhang B, Haydon RC, Zhou L, Luu HH, He TC: The e-f hand calcium-binding protein s100a4 regulates the proliferation, survival and differentiation potential of human osteosarcoma cells. Cell Physiol Biochem 2013;32:1083-1096.

44 Liu X, Qin J, Luo Q Bi Y, Zhu G, Jiang W, Kim SH, Li M, Su Y, Nan G, Cui J, Zhang W, Li R, Chen X, Kong Y, Zhang J, Wang J, Rogers MR, Zhang H, Shui W, Zhao C, Wang N, Liang X, Wu N, He Y, Luu HH, Haydon RC, Shi LL, Li T, He TC, Li M: Cross-talk between egf and bmp9 signalling pathways regulates the osteogenic differentiation of mesenchymal stem cells. J Cell Mol Med 2013;17:1160-1172.

45 Zhang W, Zhang H, Wang N, Zhao C, Zhang H, Deng F, Wu N, He Y, Chen X, Zhang J, Wen S, Liao Z, Zhang Q, Zhang Z, Liu W, Yan Z, Luu HH, Haydon RC, Zhou L, He TC: Modulation of beta-catenin signaling by the inhibitors of map kinase, tyrosine kinase, and pi3-kinase pathways. Int J Med Sci 2013;10:1888-1898.

-46 Bi Y, Huang J, He Y, Zhu GH, Su Y, He BC, Luo J, Wang Y, Kang Q, Luo Q, Chen L, Zuo GW, Jiang W, Liu B, Shi Q Tang M, Zhang BQ, Weng Y, Huang A, Zhou L, Feng T, Luu HH, Haydon RC, He TC, Tang N: Wnt antagonist sfrp3 inhibits the differentiation of mouse hepatic progenitor cells. J Cell Biochem 2009;108:295-303.

47 Huang J, Bi Y, Zhu GH, He Y, Su Y, He BC, Wang Y, Kang Q, Chen L, Zuo GW, Luo Q, Shi Q, Zhang BQ, Huang A, Zhou L, Feng T, Luu HH, Haydon RC, He TC, Tang N: Retinoic acid signalling induces the differentiation of mouse fetal liver-derived hepatic progenitor cells. Liver Int 2009;29:1569-1581.

48 Zhu GH, Huang J, Bi Y, Su Y, Tang Y, He BC, He Y, Luo J, Wang Y, Chen L, Zuo GW, Jiang W, Luo Q, Shen J, Liu B, Zhang WL, Shi Q, Zhang BQ Kang Q, Zhu J, Tian J, Luu HH, Haydon RC, Chen Y, He TC: Activation of rxr and rar signaling promotes myogenic differentiation of myoblastic c2c12 cells. Differentiation 2009;78:195204.

-49 Westerman KA, Leboulch P: Reversible immortalization of mammalian cells mediated by retroviral transfer and site-specific recombination. Proc Natl Acad Sci USA 1996;93:8971-8976.

50 Huang E, Bi Y, Jiang W, Luo X, Yang K, Gao JL, Gao Y, Luo Q, Shi Q, Kim SH, Liu X, Li M, Hu N, Liu H, Cui J, Zhang W, Li R, Chen X, Shen J, Kong Y, Zhang J, Wang J, Luo J, He BC, Wang H, Reid RR, Luu HH, Haydon RC, Yang L, He TC: Conditionally immortalized mouse embryonic fibroblasts retain proliferative activity without compromising multipotent differentiation potential. PloS One 2012;7:e32428.

51 Yang K, Chen J, Jiang W, Huang E, Cui J, Kim SH, Hu N, Liu H, Zhang W, Li R, Chen X, Kong Y, Zhang J, Wang J, Wang L, Shen J, Luu HH, Haydon RC, Lian X, Yang T, He TC: Conditional immortalization establishes a repertoire of mouse melanocyte progenitors with distinct melanogenic differentiation potential. J Invest Dermatol 2012;132:2479-2483.

-52 Li M, Chen Y, Bi Y, Jiang W, Luo Q, He Y, Su Y, Liu X, Cui J, Zhang W, Li R, Kong Y, Zhang J, Wang J, Zhang H, Shui W, Wu N, Zhu J, Tian J, Yi QJ, Luu HH, Haydon RC, He TC, Zhu GH: Establishment and characterization of the reversibly immortalized mouse fetal heart progenitors. Int J Med Sci 2013;10:1035-1046.

53 Wang J, Zhang H, Zhang W, Huang E, Wang N, Wu N, Wen S, Chen X, Liao Z, Deng F, Yin L, Zhang J, Zhang Q, Yan Z, Liu W, Zhang Z, Ye J, Deng Y, Luu HH, Haydon RC, He TC, Deng F: Bone morphogenetic protein-9 effectively induces osteo/odontoblastic differentiation of the reversibly immortalized stem cells of dental apical papilla. Stem Cells Dev 2014;23:1405-1416.

54 Lamplot JD, Liu B, Yin L, Zhang W, Wang Z, Luther G, Wagner E, Li R, Nan G, Shui W, Yan Z, Rames R, Deng F, Zhang H, Liao Z, Liu W, Zhang J, Zhang Z, Zhang Q, Ye J, Deng Y, Qiao M, Haydon RC, Luu HH, Angeles J, Shi LL, He TC, Ho SH: Reversibly immortalized mouse articular chondrocytes acquire long-term proliferative capability while retaining chondrogenic phenotype. Cell Transplant 2014. [Epub ahead of print] 
55 Luo J, Deng ZL, Luo X, Tang N, Song WX, Chen J, Sharff KA, Luu HH, Haydon RC, Kinzler KW, Vogelstein B, He TC: A protocol for rapid generation of recombinant adenoviruses using the adeasy system. Nat Protoc 2007;2:1236-1247.

56 Kang Q Song WX, Luo Q, Tang N, Luo J, Luo X, Chen J, Bi Y, He BC, Park JK, Jiang W, Tang Y, Huang J, Su Y, Zhu GH, He Y, Yin H, Hu Z, Wang Y, Chen L, Zuo GW, Pan X, Shen J, Vokes T, Reid RR, Haydon RC, Luu HH, He TC: A comprehensive analysis of the dual roles of bmps in regulating adipogenic and osteogenic differentiation of mesenchymal progenitor cells. Stem Cells Dev 2009;18:545-559.

57 Wu N, Zhang H, Deng F, Li R, Zhang W, Chen X, Wen S, Wang N, Zhang J, Yin L, Liao Z, Zhang Z, Zhang Q, Yan Z, Liu W, Wu D, Ye J, Deng Y, Yang K, Luu HH, Haydon RC, He TC: Overexpression of ad5 precursor terminal protein accelerates recombinant adenovirus packaging and amplification in hek-293 packaging cells. Gene Ther 2014;21:629-637.

-58 Hu N, Jiang D, Huang E, Liu X, Li R, Liang X, Kim SH, Chen X, Gao JL, Zhang H, Zhang W, Kong YH, Zhang J, Wang J, Shui W, Luo X, Liu B, Cui J, Rogers MR, Shen J, Zhao C, Wang N, Wu N, Luu HH, Haydon RC, He TC, Huang W: Bmp9-regulated angiogenic signaling plays an important role in the osteogenic differentiation of mesenchymal progenitor cells. J Cell Sci 2013;126:532-541.

59 Wang N, Zhang H, Zhang BQ, Liu W, Zhang Z, Qiao M, Zhang H, Deng F, Wu N, Chen X, Wen S, Zhang J, Liao Z, Zhang Q, Yan Z, Yin L, Ye J, Deng Y, Luu HH, Haydon RC, Liang H, He TC: Adenovirus-mediated efficient gene transfer into cultured three-dimensional organoids. PloS One 2014;9:e93608.

60 Wang N, Zhang W, Cui J, Zhang H, Chen X, Li R, Wu N, Chen X, Wen S, Zhang J, Yin L, Deng F, Liao Z, Zhang Z, Zhang Q Yan Z, Liu W, Ye J, Deng Y, Wang Z, Qiao M, Luu HH, Haydon RC, Shi LL, Liang H, He TC: The piggybac transposon-mediated expression of sv40 $t$ antigen efficiently immortalizes mouse embryonic fibroblasts (mefs). PloS One 2014;9:e97316.

61 Luther GA, Lamplot J, Chen X, Rames R, Wagner ER, Liu X, Parekh A, Huang E, Kim SH, Shen J, Haydon RC, He TC, Luu HH: Igfbp5 domains exert distinct inhibitory effects on the tumorigenicity and metastasis of human osteosarcoma. Cancer Lett 2013;336:222-230.

62 Wen S, Zhang H, Li Y, Wang N, Zhang W, Yang K, Wu N, Chen X, Deng F, Liao Z, Zhang J, Zhang Q, Yan Z, Liu W, Zhang Z, Ye J, Deng Y, Zhou G, Luu HH, Haydon RC, Shi LL, He TC, Wei G: Characterization of constitutive promoters for piggybac transposon-mediated stable transgene expression in mesenchymal stem cells (mscs). PloS One 2014;9:e94397.

63 Li R, Zhang W, Cui J, Shui W, Yin L, Wang Y, Zhang H, Wang N, Wu N, Nan G, Chen X, Wen S, Deng F, Zhang H, Zhou G, Liao Z, Zhang J, Zhang Q, Yan Z, Liu W, Zhang Z, Ye J, Deng Y, Luu HH, Haydon RC, He TC, Deng ZL: Targeting bmp9-promoted human osteosarcoma growth by inactivation of notch signaling. Curr Cancer Drug Targets 2014;14:274-285.

64 Gao Y, Huang E, Zhang H, Wang J, Wu N, Chen X, Wang N, Wen S, Nan G, Deng F, Liao Z, Wu D, Zhang B, Zhang J, Haydon RC, Luu HH, Shi LL, He TC: Crosstalk between wnt/beta-catenin and estrogen receptor signaling synergistically promotes osteogenic differentiation of mesenchymal progenitor cells. PloS One 2013;8:e82436.

65 Zhang J, Weng Y, Liu X, Wang J, Zhang W, Kim SH, Zhang H, Li R, Kong Y, Chen X, Shui W, Wang N, Zhao C, Wu N, He Y, Nan G, Chen X, Wen S, Zhang H, Deng F, Wan L, Luu HH, Haydon RC, Shi LL, He TC, Shi Q: Endoplasmic reticulum (er) stress inducible factor cysteine-rich with egf-like domains 2 (creld2) is an important mediator of bmp9-regulated osteogenic differentiation of mesenchymal stem cells. PloS One 2013;8:e73086.

66 Wang Y, Hong S, Li M, Zhang J, Bi Y, He Y, Liu X, Nan G, Su Y, Zhu G, Li R, Zhang W, Wang J, Zhang H, Kong Y, Shui W, Wu N, He Y, Chen X, Luu HH, Haydon RC, Shi LL, He TC, Qin J: Noggin resistance contributes to the potent osteogenic capability of bmp9 in mesenchymal stem cells. J Orthop Res 2013;31:1796-1803.

67 Zhao C, Wu N, Deng F, Zhang H, Wang N, Zhang W, Chen X, Wen S, Zhang J, Yin L, Liao Z, Zhang Z, Zhang Q, Yan Z, Liu W, Wu D, Ye J, Deng Y, Zhou G, Luu HH, Haydon RC, Si W, He TC: Adenovirus-mediated gene transfer in mesenchymal stem cells can be significantly enhanced by the cationic polymer polybrene. PloS One 2014;9:e92908.

68 Luo J, Tang M, Huang J, He BC, Gao JL, Chen L, Zuo GW, Zhang W, Luo Q, Shi Q Zhang BQ, Bi Y, Luo X, Jiang W, Su Y, Shen J, Kim SH, Huang E, Gao Y, Zhou JZ, Yang K, Luu HH, Pan X, Haydon RC, Deng ZL, He TC: Tgfbeta/ bmp type i receptors alk1 and alk2 are essential for bmp9-induced osteogenic signaling in mesenchymal stem cells. J Biol Chem 2010;285:29588-29598. 
Bi et al.: Characterization of Immortalized Hepatic Progenitors

69 Huang E, Zhu G, Jiang W, Yang K, Gao Y, Luo Q, Gao JL, Kim SH, Liu X, Li M, Shi Q, Hu N, Wang L, Liu H, Cui J, Zhang W, Li R, Chen X, Kong YH, Zhang J, Wang J, Shen J, Bi Y, Statz J, He BC, Luo J, Wang H, Xiong F, Luu HH, Haydon RC, Yang L, He TC: Growth hormone synergizes with bmp9 in osteogenic differentiation by activating the jak/stat/igf1 pathway in murine multilineage cells. J Bone Miner Res 2012;27:1566-1575.

70 He Y, Zhou JW, Xu L, Gong MJ, He TC, Bi Y: Comparison of proliferation and differentiation potential between mouse primary hepatocytes and embryonic hepatic progenitor cells in vitro. Int J Mol Med 2013;32:476484.

71 Jiang W, Zhou L, Breyer B, Feng T, Cheng H, Haydon R, Ishikawa A, He TC: Tetracycline-regulated gene expression mediated by a novel chimeric repressor that recruits histone deacetylases in mammalian cells. J Biol Chem 2001;276:45168-45174.

72 Bi Y, Gong M, He Y, Zhang X, Zhou X, Zhang Y, Nan G, Wei X, Liu Y, Chen J, Li T: Ap2alpha transcriptional activity is essential for retinoid-induced neuronal differentiation of mesenchymal stem cells. Int J Biochem Cell Biol 2014;46:148-160.

73 Su Y, Wagner ER, Luo Q, Huang J, Chen L, He BC, Zuo GW, Shi Q, Zhang BQ, Zhu G, Bi Y, Luo J, Luo X, Kim SH, Shen J, Rastegar F, Huang E, Gao Y, Gao JL, Yang K, Wietholt C, Li M, Qin J, Haydon RC, He TC, Luu $\mathrm{HH}$ : Insulin-like growth factor binding protein 5 suppresses tumor growth and metastasis of human osteosarcoma. Oncogene 2011;30:3907-3917.

74 Luu HH, Kang Q Park JK, Si W, Luo Q, Jiang W, Yin H, Montag AG, Simon MA, Peabody TD, Haydon RC, Rinker-Schaeffer CW, He TC: An orthotopic model of human osteosarcoma growth and spontaneous pulmonary metastasis. Clin Exp Metastasis 2005;22:319-329.

75 Luo X, Chen J, Song WX, Tang N, Luo J, Deng ZL, Sharff KA, He G, Bi Y, He BC, Bennett E, Huang J, Kang Q, Jiang W, Su Y, Zhu GH, Yin H, He Y, Wang Y, Souris JS, Chen L, Zuo GW, Montag AG, Reid RR, Haydon RC, Luu $\mathrm{HH}, \mathrm{He}$ TC: Osteogenic bmps promote tumor growth of human osteosarcomas that harbor differentiation defects. Lab Invest 2008;88:1264-1277.

76 Rastegar F, Gao JL, Shenaq D, Luo Q Shi Q Kim SH, Jiang W, Wagner ER, Huang E, Gao Y, Shen J, Yang K, He BC, Chen L, Zuo GW, Luo J, Luo X, Bi Y, Liu X, Li M, Hu N, Wang L, Luther G, Luu HH, Haydon RC, He TC: Lysophosphatidic acid acyltransferase beta (lpaatbeta) promotes the tumor growth of human osteosarcoma. PloS One 2010;5:e14182.

77 Crosby HA, Kelly DA, Strain AJ: Human hepatic stem-like cells isolated using c-kit or cd34 can differentiate into biliary epithelium. Gastroenterology 2001;120:534-544.

78 Niwa H, Miyazaki J, Smith AG: Quantitative expression of oct-3/4 defines differentiation, dedifferentiation or self-renewal of es cells. Nat Genet 2000;24:372-376.

79 Nishina H: Hdlk-1: A cell surface marker common to normal hepatic stem/progenitor cells and carcinomas. J Biochem 2012;152:121-123.

-80 Kuhlmann WD, Peschke P: Hepatic progenitor cells, stem cells, and afp expression in models of liver injury. Int J Exp Pathol 2006;87:343-359.

81 Pan RL, Chen Y, Xiang LX, Shao JZ, Dong XJ, Zhang GR: Fetal liver-conditioned medium induces hepatic specification from mouse bone marrow mesenchymal stromal cells: A novel strategy for hepatic transdifferentiation. Cytotherapy 2008;10:668-675.

-82 Tirnitz-Parker JE, Tonkin JN, Knight B, Olynyk JK, Yeoh GC: Isolation, culture and immortalisation of hepatic oval cells from adult mice fed a choline-deficient, ethionine-supplemented diet. Int J Biochem Cell Biol 2007;39:2226-2239.

-83 Costa RH, Kalinichenko VV, Holterman AX, Wang X: Transcription factors in liver development, differentiation, and regeneration. Hepatology 2003;38:1331-1347.

84 Kaestner KH: The foxa factors in organogenesis and differentiation. Curr Opin Genet Dev 2010;20:527-532.

85 Yamada T, Yoshikawa M, Kanda S, Kato Y, Nakajima Y, Ishizaka S, Tsunoda Y: In vitro differentiation of embryonic stem cells into hepatocyte-like cells identified by cellular uptake of indocyanine green. Stem Cells 2002;20:146-154.

86 Changyong C, Sun M, Li H, Brockmeyer N, Wu NP: Simian virus 40 inhibits differentiation and maturation of rhesus macaque dc-sign(+) dendritic cells. Eur J Med Res 2010;15:377-382.

87 Jackson-Cook C, Zou Y, Turner K, Astbury C, Ware J: A novel tumorigenic human prostate epithelial cell line (m2205): Molecular cytogenetic characterization demonstrates c-myc amplification and jumping translocations. Cancer Genet Cytogenet 2003;141:56-64. 
Bi et al.: Characterization of Immortalized Hepatic Progenitors

88 Soto-Gutierrez A, Navarro-Alvarez N, Yagi H, Yarmush ML: Stem cells for liver repopulation. Curr Opin Organ Transplant 2009;14:667-673.

89 Liu YN, Zhang J, He QH, Dai X, Shen L: Isolation and characterization of epithelial progenitor cells from human fetal liver. Hepatol Res 2008;38:103-113.

90 Heo J, Factor VM, Uren T, Takahama Y, Lee JS, Major M, Feinstone SM, Thorgeirsson SS: Hepatic precursors derived from murine embryonic stem cells contribute to regeneration of injured liver. Hepatology 2006;44:1478-1486.

91 Amicone L, Spagnoli FM, Spath G, Giordano S, Tommasini C, Bernardini S, De Luca V, Della Rocca C, Weiss MC, Comoglio PM, Tripodi M: Transgenic expression in the liver of truncated met blocks apoptosis and permits immortalization of hepatocytes. EMBO J 1997;16:495-503.

-92 Spagnoli FM, Amicone L, Tripodi M, Weiss MC: Identification of a bipotential precursor cell in hepatic cell lines derived from transgenic mice expressing cyto-met in the liver. J Cell Biol 1998;143:1101-1112.

-93 Fougere-Deschatrette C, Imaizumi-Scherrer T, Strick-Marchand H, Morosan S, Charneau P, Kremsdorf D, Faust DM, Weiss MC: Plasticity of hepatic cell differentiation: Bipotential adult mouse liver clonal cell lines competent to differentiate in vitro and in vivo. Stem Cells 2006;24:2098-2109.

$\$ 94$ Hirata M, Amano K, Miyashita A, Yasunaga M, Nakanishi T, Sato K: Establishment and characterization of hepatic stem-like cell lines from normal adult rat liver. J Biochem 2009;145:51-58.

$\$ 95$ Kamiya A, Kakinuma S, Yamazaki Y, Nakauchi H: Enrichment and clonal culture of progenitor cells during mouse postnatal liver development in mice. Gastroenterology 2009;137:1114-1126, 1126 e1111-1114.

-96 Allain JE, Dagher I, Mahieu-Caputo D, Loux N, Andreoletti M, Westerman K, Briand P, Franco D, Leboulch P, Weber A: Immortalization of a primate bipotent epithelial liver stem cell. Proc Natl Acad Sci USA 2002;99:3639-3644.

97 Delgado JP, Parouchev A, Allain JE, Pennarun G, Gauthier LR, Dutrillaux AM, Dutrillaux B, Di Santo J, Capron F, Boussin FD, Weber A: Long-term controlled immortalization of a primate hepatic progenitor cell line after simian virus 40 t-antigen gene transfer. Oncogene 2005;24:541-551.

-98 Weiss TS, Lichtenauer M, Kirchner S, Stock P, Aurich H, Christ B, Brockhoff G, Kunz-Schughart LA, Jauch KW, Schlitt HJ, Thasler WE: Hepatic progenitor cells from adult human livers for cell transplantation. Gut 2008;57:1129-1138.

99 Aaronson SA, Todaro GJ: Development of 3t3-like lines from balb-c mouse embryo cultures: Transformation susceptibility to sv40. J Cell Physiol 1968;72:141-148.

100 vom Brocke J, Schmeiser HH, Reinbold M, Hollstein M: Mef immortalization to investigate the ins and outs of mutagenesis. Carcinogenesis 2006;27:2141-2147.

101 Jha KK, Banga S, Palejwala V, Ozer HL: Sv40-mediated immortalization. Exp Cell Res 1998;245:1-7.

102 Borowiec JA, Dean FB, Bullock PA, Hurwitz J: Binding and unwinding--how t antigen engages the sv40 origin of DNA replication. Cell 1990;60:181-184.

103 Prives C: The replication functions of sv40 $t$ antigen are regulated by phosphorylation. Cell 1990;61:735738.

104 Zhu JY, Abate M, Rice PW, Cole CN: The ability of simian virus 40 large t antigen to immortalize primary mouse embryo fibroblasts cosegregates with its ability to bind to p53. J Virol 1991;65:6872-6880. 